\title{
Evaluation of Ruthenium Capture Methods for Tritium Pretreatment Off-Gas Streams
}

\section{Nuclear Technology}

Research and Development

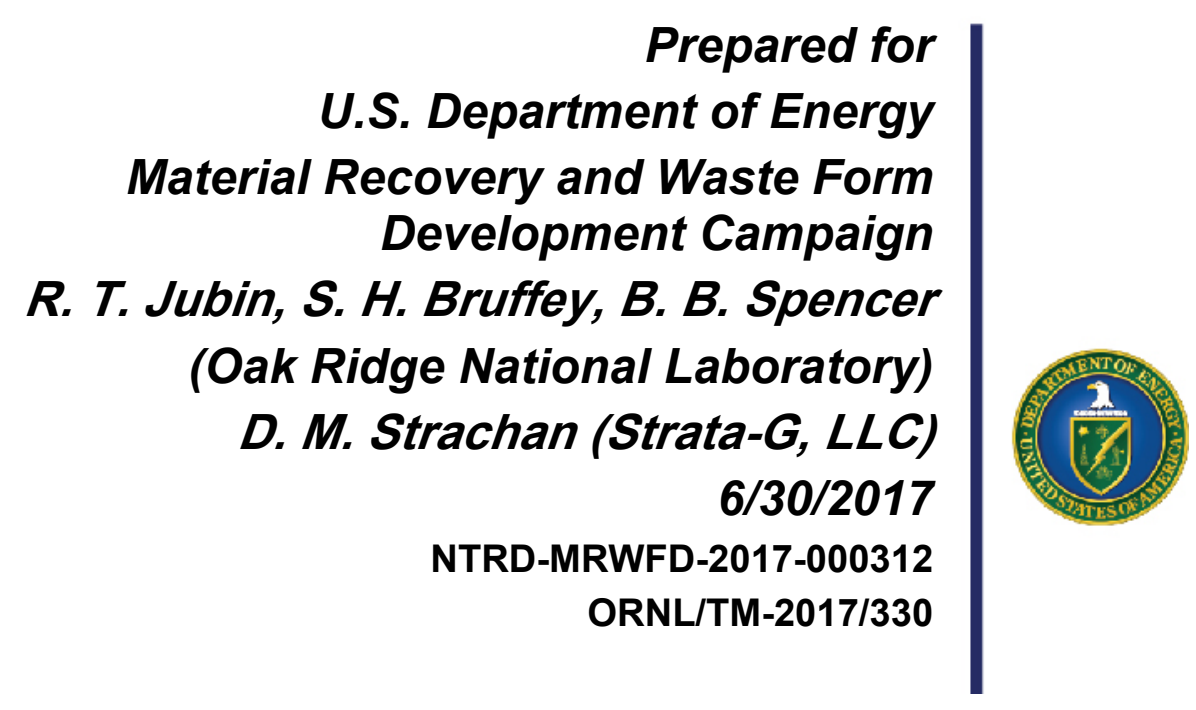




\section{DOCUMENT AVAILABILITY}

Reports produced after January 1, 1996, are generally available free via US Department of Energy (DOE) SciTech Connect.

Website http://www.osti.gov/scitech/

Reports produced before January 1, 1996, may be purchased by members of the public from the following source:

National Technical Information Service

5285 Port Royal Road

Springfield, VA 22161

Telephone 703-605-6000 (1-800-553-6847)

TDD 703-487-4639

Fax 703-605-6900

E-mail info@ntis.gov

Website http://www.ntis.gov/help/ordermethods.aspx

Reports are available to DOE employees, DOE contractors, Energy Technology Data Exchange representatives, and International Nuclear Information System representatives from the following source:

Office of Scientific and Technical Information

PO Box 62

Oak Ridge, TN 37831

Telephone 865-576-8401

Fax 865-576-5728

E-mail reports@osti.gov

Website http://www.osti.gov/contact.html

This report was prepared as an account of work sponsored by an agency of the United States Government. Neither the United States Government nor any agency thereof, nor any of their employees, makes any warranty, express or implied, or assumes any legal liability or responsibility for the accuracy, completeness, or usefulness of any information, apparatus, product, or process disclosed, or represents that its use would not infringe privately owned rights. Reference herein to any specific commercial product, process, or service by trade name, trademark, manufacturer, or otherwise, does not necessarily constitute or imply its endorsement, recommendation, or favoring by the United States Government or any agency thereof. The views and opinions of authors expressed herein do not necessarily state or reflect those of the United States Government or any agency thereof. 


\section{SUMMARY}

In the reprocessing of used nuclear fuel, radioactive elements are released into various plant off-gas streams. While much research and development has focused on the abatement of the volatile nuclides ${ }^{3} \mathrm{H}$, ${ }^{14} \mathrm{C},{ }^{85} \mathrm{Kr}$, and ${ }^{129} \mathrm{I}$, the potential release of semivolatile isotopes that could also report to the off-gas streams in a reprocessing facility has been examined. Ruthenium (as ${ }^{106} \mathrm{Ru}$ ) has been identified as one of the semivolatile nuclides requiring the greatest degree of abatement prior to discharging the plant off-gas to the environment.

A recent engineering evaluation of an integrated off-gas system for the head-end off-gas stream of a reprocessing facility included $\mathrm{Ru}$ capture systems for both the dissolver off-gas and the tritium pretreatment system off-gas. The design of a Ru capture system was noted as challenging due to the lack of critical data on both Ru volatilization from specific unit operations and on gaseous Ru removal by solid sorbents in relevant systems. In traditional aqueous reprocessing, the amounts of $\mathrm{Ru}$ volatilized during shearing and dissolution are expected to be low. However, to prevent the partitioning of ${ }^{3} \mathrm{H}$ into the aqueous streams within the plant, upfront dry pretreatment steps, known as tritium pretreatment, have been developed to oxidize the fuel prior to dissolution and release the ${ }^{3} \mathrm{H}$ into the plant off-gas. Little is known regarding the amount of gaseous $\mathrm{Ru}$ released during these pretreatment steps, but in most cases the quantities of $\mathrm{Ru}$ released are assumed to be greater than those released when dissolution is performed directly after fuel shearing. Thermodynamically, $\mathrm{Ru}$ is expected to present as $\mathrm{RuO}_{4}$ within the temperature ranges of tritium pretreatment processes, but this assumption requires verification.

Beyond the questions associated with the $\mathrm{Ru}$ source term, the recent engineering evaluation identified outstanding questions related to $\mathrm{Ru}$ removal by solid sorbents, including (1) the partitioning of $\mathrm{Ru}$ between solid, volatile, and particulate forms; (2) the degree of Ru abatement by other off-gas processes; and (3) the capacity of common sorbents for Ru.

Silica gel is the most extensively studied Ru adsorber, and some studies have reported the capacity of silica gel for $\mathrm{Ru}$ in a flowing system. However, much of the reported work on silica gel was performed in a humid environment, which does not translate directly to $\mathrm{Ru}$ adsorption from the off-gas of a dry tritium pretreatment process. Some research has been performed on the adsorption of Ru by metal fibers or metal oxides. Many studies have examined the deposition of $\mathrm{Ru}$ on stainless steel and can provide insight into the speciation and the loading of $\mathrm{Ru}$ as a function of surface area, but practical engineering data on $\mathrm{Ru}$ adsorption by metal sorbents remain unreported.

The literature reviews and calculations detailed in this report provided a basis for the design of an experimental system, an analytical method, and a test plan. The difficulties in handling Ru-bearing gas streams, from both safety and practicality perspectives, drove the decision to propose a very simple test system and a proposed test design.

It is intended that the proposed series of testing will provide (1) $\mathrm{Ru}$ breakthrough time and $\mathrm{Ru}$ loading capacity of metal mesh in a dry stream, (2) Ru breakthrough time and Ru loading capacity of silica gel in a dry stream, and (3) Ru desorption from silica gel as a function of time ( $\mathrm{mg} \mathrm{h}^{-1} \mathrm{~g}^{-1}$ loaded silica). In addition, some information, such as the length of the mass transfer zone, may be obtained through successful leaching of the sorbent beds. Finally, any experimental data gathered on Ru quantitation by either ultraviolet-visible spectroscopy or neutron activation analysis may augment the literature available on the subject of $\mathrm{Ru}$ analysis. Much of the information intended to be collected from this testing will be directly useful in the refinement of $\mathrm{Ru}$ abatement system designs such as those included in the engineering evaluation of an integrated off-gas system for the head-end off-gas stream of a reprocessing facility (Jubin et al. 2016). 


\section{CONTENTS}

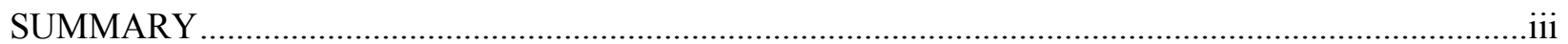

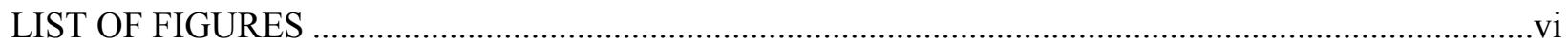

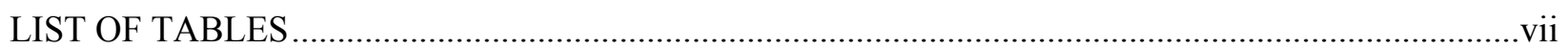

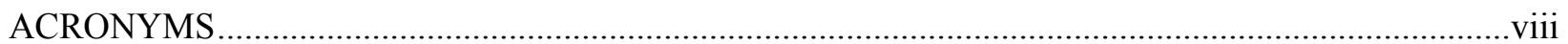

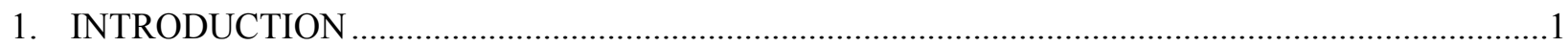

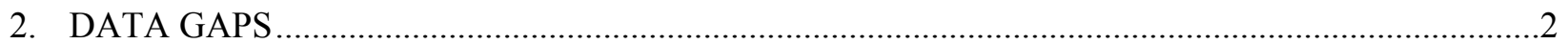

3. RUTHENIUM SOURCE TERM AND CHEMISTRY RELEVANT TO TRITIUM PRETREATMENT AND RUTHENIUM RETENTION …........................................................

3.1 Tritium Pretreatment Processes and Their Implications for Ru Volatilization from Used

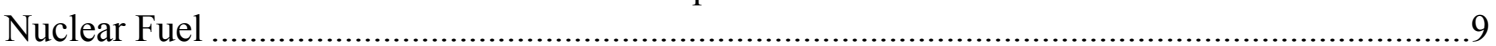

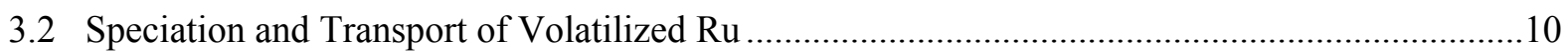

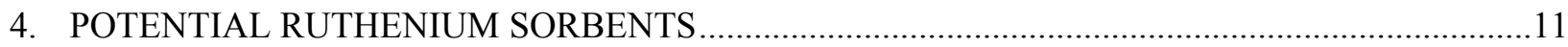

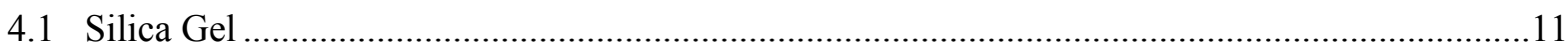

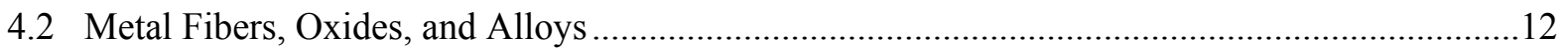

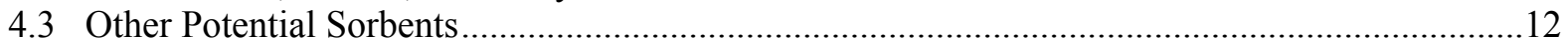

5. PROPOSED EXPERIMENTAL SYSTEM FOR EVALUATION

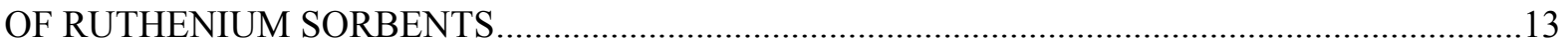

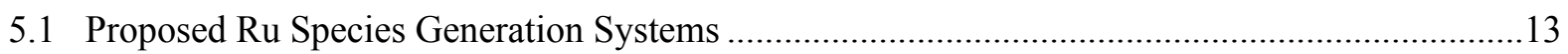

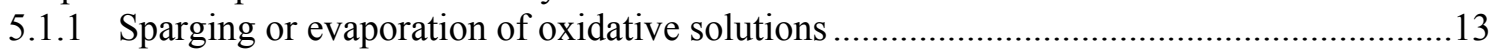

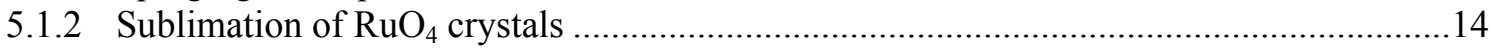

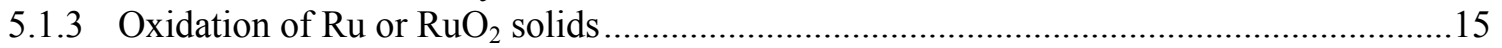

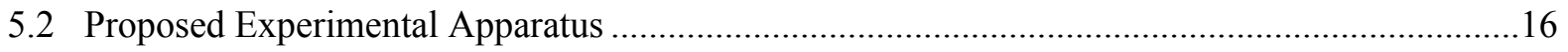

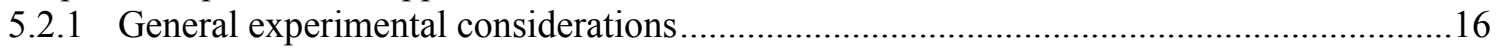

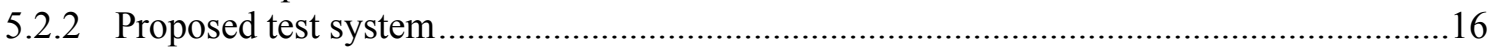

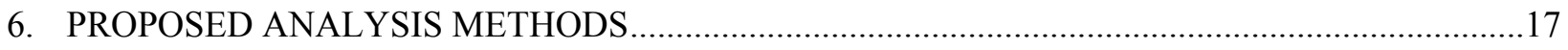

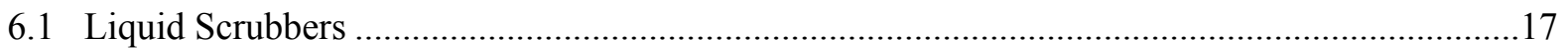

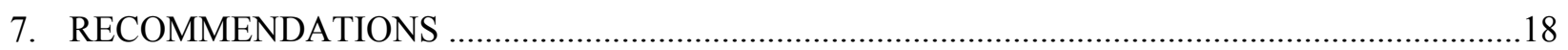

7.1 Characterization of Ru Generation and Deposition within the Test System.............................18

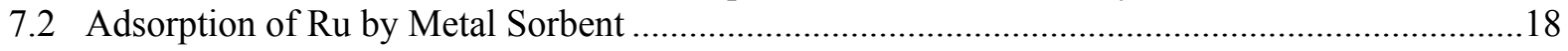

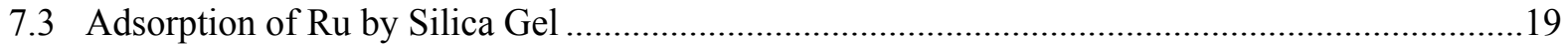

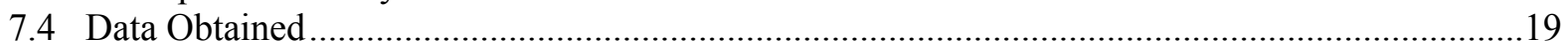

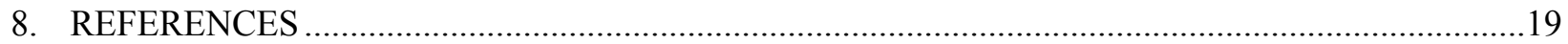




\section{LIST OF FIGURES}

Figure 1. Evaporative/sparging system of the type described by Cains and Yewer (1985).....................14

Figure 2. $\mathrm{RuO}_{4}$ crystalline generator of the type described by Holm et al. (2009). .................................15

Figure 3. Dry volatilization system of the type described by Maas and Longo (1979)............................16

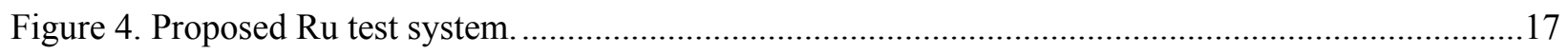




\section{LIST OF TABLES}

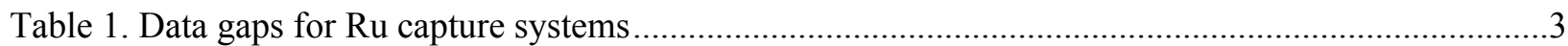

Table 2. Mass of Ru isotopes in used nuclear fuel ( $\mathrm{g} / \mathrm{tIHM}$ ) as a function of cooling time* ......................8

Table 3. Activity of Ru radioisotopes in used nuclear fuel (Ci/tIHM) as a function of cooling time* 


\section{ACRONYMS}

$\begin{array}{ll}\text { ATPOG } & \text { advanced tritium pretreatment off-gas } \\ \text { DF } & \text { decontamination factor } \\ \text { FY } & \text { fiscal year } \\ \text { HEPA } & \text { high efficiency particulate air } \\ \text { HLW } & \text { high level waste } \\ \text { ICP-MS } & \text { inductively coupled plasma-mass spectrometry } \\ \text { IHM } & \text { initial heavy metal } \\ \text { LLW } & \text { low level waste } \\ \text { MEI } & \text { maximum exposed individual } \\ \text { ORNL } & \text { Oak Ridge National Laboratory } \\ \text { ppmv } & \text { parts per million by volume } \\ \text { PWR } & \text { pressurized water reactor } \\ \text { TBD } & \text { to be determined } \\ \text { TPT } & \text { tritium pretreatment } \\ \text { TPTOG } & \text { tritium pretreatment off-gas } \\ \text { UNF } & \text { used nuclear fuel } \\ \text { UV-Vis } & \text { ultraviolet-visible }\end{array}$




\section{INTRODUCTION}

The reprocessing of used nuclear fuel (UNF) results in the release of radioactive elements into various plant off-gas streams. In previous reports, the in-plant distribution pathways and abatement requirements for four radionuclides known to be volatile (i.e., ${ }^{14} \mathrm{C},{ }^{3} \mathrm{H},{ }^{129} \mathrm{I}$, and ${ }^{85} \mathrm{Kr}$ ) have been discussed in detail (Jubin et al. 2012b; Soelberg et al. 2013; Jubin et al. 2011, 2012a; Jubin et al. 2013). A recent report by Jubin et al. (2014) examined the potential release of other less-volatile (semivolatile) isotopes that could also report to the off-gas streams in a reprocessing facility. In that study, an effort was made to determine which, if any, of 24 semivolatile radionuclides could be released from a reprocessing plant and, if so, the likely quantities released. Of these 24 semivolatile radionuclides, ruthenium $(\mathrm{Ru})$, in particular ${ }^{106} \mathrm{Ru}$, was identified as one of the semivolatile nuclides that could require the greatest degree of abatement prior to discharge of the plant off-gas to the environment. The study was followed by an engineering evaluation of an integrated off-gas system for the head-end off-gas stream of a reprocessing facility (Jubin et al. 2016). This design included $\mathrm{Ru}$ capture systems for both the dissolver off-gas and the tritium pretreatment system off-gas (TPTOG).

The design of a $\mathrm{Ru}$ capture system proved challenging due to the lack of critical data on both $\mathrm{Ru}$ volatilization from specific unit operations and on gaseous $\mathrm{Ru}$ removal by solid sorbents in relevant systems. In traditional aqueous reprocessing, the head-end portion of the process includes fuel shearing and subsequent fuel dissolution in nitric acid. The nitric acid solution is known to volatilize some portion of the $\mathrm{Ru}$ contained in the fuel meat (likely $<0.1 \%$ ) along with iodine, krypton, and carbon dioxide, into the dissolver off-gas (Voskresenskaya et al. 2014a.) The bulk of the ${ }^{3} \mathrm{H}$ remains in the nitric acid and is distributed throughout the aqueous waste streams within the plant. To prevent the partitioning of ${ }^{3} \mathrm{H}$ into the aqueous streams within the plant, upfront dry pretreatment steps, known as tritium pretreatment (TPT), have been developed to oxidize the fuel prior to dissolution and release the ${ }^{3} \mathrm{H}$ into the plant offgas (Goode and Stacy 1980, Del Cul et al. 2012). Little is known regarding the amount of gaseous Ru released during these pretreatment steps, but in most cases, it is assumed that the quantities of Ru released are greater than those released when dissolution is performed directly after fuel shearing (Cadieux and Stone 1980, Johnson and Stone 1977, Goode 1973).

Beyond the questions associated with the Ru source term, Jubin et al. (2016) identified a number of data gaps in the course of engineering design that are related to Ru removal by solid sorbents. For example, one of the observations from the engineering evaluation was the surprising lack of consistency in the literature on the use of silica gel to remove volatile $\mathrm{Ru}$ and on the gaseous $\mathrm{Ru}$ speciation in the off-gas streams. Silica gel was reported by Goossens (1991) to have Ru loadings of $2.6 \mathrm{~kg} / \mathrm{m}^{3}$. In contrast, Cains and Yewer (1985) report silica gel as unsuitable for $\mathrm{Ru}$ abatement. Other potential sorbents include a bed of metal fibers or metal oxides, but these sorbents have been evaluated only for Ru surface deposition, not for use in abatement beds (Cains and Yewer 1985, Holm et al. 2009, Sakurai et al. 1985).

This report is a summary of a literature review of relevant information for Ru capture from TPT operations. This review was conducted to provide the technical basis for the design of an experimental system and a test plan with which the identified data gaps could be addressed. This report only briefly discusses questions regarding the $\mathrm{Ru}$ source term and focuses on $\mathrm{Ru}$ capture from gaseous streams. The specific aims of the literature review are to

1) review relevant technical information on the subject of $\mathrm{Ru}$ removal from a TPTOG stream (including an expanded review focused on identifying expected $\mathrm{Ru}$ species);

2) provide a summary of methods to produce, in a controlled manner, the expected Ru species; and

3) summarize analytical methods that can be used to differentiate the Ru species.

The information provided in the technical review then allows recommendations to be made regarding the design of an experimental plan to evaluate Ru retention capacity, adsorption rate, capture efficiency, and 
nature of $\mathrm{Ru}$ species not retained for proposed $\mathrm{Ru}$ sorbent materials. The initial experimental work is intended to begin in FY 2017.

\section{DATA GAPS}

Jubin et al. (2016) identified several specific data gaps that affected the design of the Ru capture system:

- The required $\mathrm{Ru}$ decontamination is known to be high, but there is still uncertainty in the specific requirements. An overall Ru plant decontamination factor (DF) of $3.04 \times 10^{7}$ is needed for $5 \mathrm{y}$ cooled $60 \mathrm{GWd} / \mathrm{tIHM}$ fuel. A review of the literature supports a DF value of about $1 \times 10^{4}$. The discrepancy arises from some differences in the literature regarding the conversion of volatile $\mathrm{RuO}_{4}$ to particulate $\mathrm{RuO}_{2}$ in the gas phase and regarding the capture methods and efficiencies for these volatile and particulate forms of $\mathrm{Ru}$. In addition, the degree of $\mathrm{Ru}$ abatement by other offgas processes (including filters, adsorbers, condensers, wet scrubbers, etc.) is not well known, and any $\mathrm{Ru}$ abatement by these processes is likely affected by the equilibria between $\mathrm{RuO}_{4}$ and $\mathrm{RuO}_{2}$. Further, the efficiencies of HEPA filters for particulate $\mathrm{RuO}_{2}$ and of aqueous scrubbers for volatile $\mathrm{RuO}_{4}$ are uncertain.

- Improved data are needed on the volatilization of Ru during TPT. Data are needed relative to the relationship between quantity of $\mathrm{Ru}$ released, gaseous $\mathrm{Ru}$ speciation, and operating conditions (e.g., temperature, time, oxygen content).

- Few data exist on the Ru capacity of metal and metal oxides, preventing the consideration of this sorbent material by Jubin et al. (2016).

Other data gaps were embedded in the assumptions used in the engineering design:

- Material balance calculations were based on $10 \%$ of the Ru contained in the fuel being volatilized into the off-gas during TPT. However, early work on TPT suggests that very little Ru is volatilized (Cadieux and Stone 1980, Johnson and Stone 1977, Goode 1973), likely $<0.1 \%$.

- A back-flushable HEPA filter could be utilized to protect the Ru adsorber from fuel particulates. Klein et al. (1980) indicates that the Ru deposited on a filter must be washed off and cannot be removed with a blow-back. It was assumed that $90 \%$ of the Ru would be captured on the backflushable filter (an effective Ru DF of 10). In general, the HEPA filter DF for particles greater than about $0.3 \mu \mathrm{m}$ (DOE 2003) can be as high as $3 \times 10^{4}$.

- It was assumed that combining the DF values of successive removal methods (i.e., HEPA filter, scrubbers, Ru solid sorbent bed) would achieve the desired overall DF for Ru removal.

A full evaluation of these data gaps and the test systems that could be used in their resolution was documented by Jubin et al. (2017). This evaluation was performed for each of the main off-gas treatment unit operations and for the overall treatment train. The resulting data requirements are identified in tabular form in Jubin et al. (2017), and a summary of those are shown here (Table 1) for context. It was recognized that significant gaps existed in the source terms arising from TPT operations and from fuel dissolution, but the evaluation limited the scope of the study to the off-gas capture systems themselves. The proposed experimental system and test design provided in Sections 5 and 7 of this report were informed by this analysis and are intended to facilitate proof-of-principle testing that will begin to address these gaps for two types of sorbent for use in standard TPTOG. 
Table 1. Data gaps for Ru capture systems

\begin{tabular}{|c|c|c|c|}
\hline \# & Property & Specific requirements & Approach \\
\hline \multicolumn{4}{|c|}{ Metrics for technical performance and physical and chemical characteristics criterion } \\
\hline 1 & $\begin{array}{l}\text { Adsorption capacity } \\
\text { mol/kg sorbent }\end{array}$ & $\begin{array}{l}\text { Maximum capacity of } \\
\text { selected sorbent material as a } \\
\text { function of } \mathrm{Ru} \text { species, } \\
\text { temperature, and } \\
\text { concentration } \\
\text { - } \mathrm{Ru} \text { species of interest are } \\
\mathrm{TBD} \text { but may include } \\
\mathrm{RuO}_{4}, \mathrm{RuI}_{4} \text {, and } \mathrm{RuBr}_{4} \\
\text { - Operating temperature } \\
\text { range is } 30 \text { to } 600^{\circ} \mathrm{C} \\
\text { - } \mathrm{Ru} \text { concentration ranging } \\
\text { from } 1 \times 10^{-7} \mathrm{~kg} / \mathrm{m}^{3} \text { to } 1 \times \\
10^{-4} \mathrm{~kg} / \mathrm{m}^{3} \\
\text { - Gas velocities ranging } \\
\text { from } 5 \text { to } 100 \mathrm{~m} / \mathrm{min}^{\circ}\end{array}$ & $\begin{array}{l}\text { Thin bed testing } \\
\text { Test system must be able to hold a thin } \\
\text { bed of sorbent at given temperature } \\
\text { and expose sorbent to a generated air } \\
\text { stream containing water (and any } \\
\text { potentially co-adsorbed species) at } \\
\text { varying concentrations within the } \\
\text { specified concentration range and gas } \\
\text { velocity }\end{array}$ \\
\hline 2 & $\begin{array}{l}\text { Capture/removal rates for } \\
\text { primary species } \\
\mathrm{mol} / \mathrm{kg} \mathrm{sorbent/h}\end{array}$ & $\begin{array}{l}\text { Adsorption rate data for } \\
\text { selected sorbent as function } \\
\text { of Ru species, temperature, } \\
\text { and concentration } \\
\text { Recommended experimental } \\
\text { ranges and Ru species are } \\
\text { provided in Gap ID \#1 }\end{array}$ & $\begin{array}{l}\text { Thin bed testing } \\
\text { (See Gap ID \#1) }\end{array}$ \\
\hline 3 & $\begin{array}{l}\text { Capacity for other species } \\
\text { present in gas stream } \\
\mathrm{mol} / \mathrm{kg} \text { sorbent }\end{array}$ & $\begin{array}{l}\text { Maximum capacity for } \\
\text { potential co-absorbed species } \\
\text { by selected sorbent material } \\
\text { as a function of species, } \\
\text { temperature, and } \\
\text { concentration } \\
\text { - Species of interest are } \\
\mathrm{H}_{2} \mathrm{O}, \mathrm{O}_{2}, \mathrm{~N}_{2}, \mathrm{HNO}_{3}, \mathrm{CO}_{2} \text {, } \\
\mathrm{I}, \text { etc. } \\
\text { - } \mathrm{H}_{2} \mathrm{O} \text { with a dew point of } \\
-60 \text { to } 90{ }^{\circ} \mathrm{C} \\
\text { - } \mathrm{HNO}_{3} \text { concentration of } \\
1000 \text { ppm } \\
\text { - } \mathrm{O}_{2} \text { concentrations of } 20 \text { to } \\
\sim 100 \% \\
\text { - } \mathrm{N}_{2} \text { concentrations of } 0 \text { to } \\
80 \% \\
\text { - } \mathrm{CO}_{2} \text { concentrations of } 440 \\
\text { ppm } \\
\text { - } \mathrm{I}^{\circ} \text { concentrations up to } 0.1 \\
\mathrm{~kg}^{\circ} \mathrm{m}^{3}(10,000 \text { ppm) }\end{array}$ & $\begin{array}{l}\text { Thin bed testing } \\
\text { (See Gap ID \#1) }\end{array}$ \\
\hline
\end{tabular}




\begin{tabular}{|c|c|c|c|}
\hline$\#$ & Property & Specific requirements & Approach \\
\hline & & $\begin{array}{l}\text { - Operating temperature } \\
\text { range is } 30 \text { to } 600^{\circ} \mathrm{C}\end{array}$ & \\
\hline 4 & $\begin{array}{l}\text { Capture/removal rate for } \\
\text { co-absorbed species } \\
\text { mol/kg sorbent } / \mathrm{h}\end{array}$ & $\begin{array}{l}\text { Adsorption rate data for } \\
\text { selected sorbent as function } \\
\text { of co-absorbed species, } \\
\text { temperature, and } \\
\text { concentration } \\
\text { Recommended experimental } \\
\text { ranges and potentially co- } \\
\text { adsorbing species are } \\
\text { provided in Gap ID \#3 }\end{array}$ & $\begin{array}{l}\text { Thin bed testing } \\
\text { (See Gap ID \#1) }\end{array}$ \\
\hline 5 & $\begin{array}{l}\text { Change in sorbent } \\
\text { capacity for } \mathrm{Ru} \text { in } \\
\text { presence of other species } \\
\text { present in gas stream } \\
\mathrm{mol} / \mathrm{kg} \text { sorbent }\end{array}$ & $\begin{array}{l}\text { Ru capacity of selected } \\
\text { sorbent material for potential } \\
\text { adverse effects to Ru capacity } \\
\text { in the presence of co- } \\
\text { absorbed species function of } \\
\text { species, temperature, and } \\
\text { concentration } \\
\text { Recommended experimental } \\
\text { ranges, Ru species, and } \\
\text { potentially co-adsorbing } \\
\text { species are provided in Gap } \\
\text { IDs \#1 and \#3 }\end{array}$ & $\begin{array}{l}\text { Thin bed testing with post-adsorption } \\
\text { sorbent analysis } \\
\text { Thin bed testing (see Gap ID \#1) using } \\
\text { selected sorbent followed by chemical } \\
\text { or gamma analysis of sorbent }\end{array}$ \\
\hline 6 & $\begin{array}{l}\text { Change in Ru capture rate } \\
\text { in presence of co-absorbed } \\
\text { species } \\
\mathrm{mol} / \mathrm{kg} \mathrm{sorbent/h}\end{array}$ & $\begin{array}{l}\text { Ru adsorption rate data for } \\
\text { selected sorbent as function } \\
\text { of co-absorbed species, } \\
\text { temperature, and } \\
\text { concentration } \\
\text { Recommended experimental } \\
\text { ranges, Ru species, and } \\
\text { potentially co-adsorbing } \\
\text { species are provided in Gap } \\
\text { IDs \#1 and \#3 }\end{array}$ & $\begin{array}{l}\text { Thin bed testing with post-adsorption } \\
\text { sorbent analysis } \\
\text { (See Gap ID \#5) }\end{array}$ \\
\hline 7 & $\begin{array}{l}\text { Selectivity } \\
\left(X_{a} / Y_{a}\right) /\left(X_{b} / Y_{b}\right) \\
\text { (unitless) } \\
\text { Where } X_{a} \text { and } X_{b} \text { are mole } \\
\text { fractions of species a and } b \\
\text { respectively in the adsorbed } \\
\text { phase, and } Y_{a} \text { and } Y_{b} \text { are } \\
\text { mole fractions of species a } \\
\text { and b in the bulk phase }\end{array}$ & $\begin{array}{l}\text { Derived from data on co- } \\
\text { absorption studies shown } \\
\text { above }\end{array}$ & $\begin{array}{l}\text { Thin bed testing with post-adsorption } \\
\text { sorbent analysis } \\
\text { (See Gap ID \#5) }\end{array}$ \\
\hline
\end{tabular}




\begin{tabular}{|c|c|c|c|}
\hline \# & Property & Specific requirements & Approach \\
\hline 8 & $\begin{array}{l}\text { Sorbent particle density } \\
\mathrm{kg} / \mathrm{m}^{3}\end{array}$ & $\begin{array}{l}\text { Density of individual } \\
\text { particles in } \mathrm{kg} / \mathrm{m}^{3}\end{array}$ & $\begin{array}{l}\text { Direct measurement or from } \\
\text { manufacturer }\end{array}$ \\
\hline 9 & $\begin{array}{l}\text { Sorbent bulk density } \\
\mathrm{kg} / \mathrm{m}^{3}\end{array}$ & $\begin{array}{l}\text { Bulk density of bed of } \\
\text { sorbent material in typical } \\
\text { loading configuration in } \\
\mathrm{kg} / \mathrm{m}^{3}\end{array}$ & $\begin{array}{l}\text { Direct measurement or from } \\
\text { manufacturer }\end{array}$ \\
\hline 10 & $\begin{array}{l}\text { Specific heat capacity } \\
\mathrm{J} / \mathrm{K} / \mathrm{kg}\end{array}$ & $\begin{array}{l}\text { Specific heat capacity of } \\
\text { fresh and loaded sorbent over } \\
\text { range of operating conditions } \\
\left(30 \text { to } 600{ }^{\circ} \mathrm{C}\right)\end{array}$ & $\begin{array}{l}\text { Direct measurement of fresh sorbent } \\
\text { and loaded sorbent. }\end{array}$ \\
\hline 11 & $\begin{array}{l}\text { Thermal conductivity } \\
W / m / K\end{array}$ & $\begin{array}{l}\text { Thermal conductivity of fresh } \\
\text { and loaded sorbent over range } \\
\text { of operating conditions ( } 30 \text { to } \\
600^{\circ} \mathrm{C} \text { ) }\end{array}$ & $\begin{array}{l}\text { Direct measurement of fresh sorbent } \\
\text { and loaded sorbent. }\end{array}$ \\
\hline 12 & $\begin{array}{l}\text { Radiation stability } \\
\text { \% degradation in capacity, } \\
\text { adsorption rate, } \\
\text { regeneration time, and } M T Z \\
\text { over time as a function of } \\
\text { radiation exposure }\end{array}$ & $\begin{array}{l}\text { Total adsorbed dose for } \mathrm{Ru} \\
\text { sorbents assume one time use, } \\
\text { i.e., no regeneration } \\
\text { Total Dose requirement is } \\
\text { TBD and design dependent } \\
\text { Total dose should factor in } \\
\text { both external dose and } \\
\text { internal dose }\end{array}$ & $\begin{array}{l}\text { Irradiation and thin bed testing } \\
\text { Exposure of the sorbent to both } \gamma \text { and } \beta \\
\text { radiation for a range of total doses. } \\
\text { Testing of the sorbent with both thin } \\
\text { and deep bed testing to characterize } \\
\text { radiation effects. } \\
\text { (Thin bed testing: See Gap IDs \#1 and } \\
\# 5)\end{array}$ \\
\hline 13 & $\begin{array}{l}\text { Mechanical stability } \\
\text { N/mm (load vs particle } \\
\text { diameter) } \\
\mu g / k g \text { sorbent loss to gas } \\
\text { stream }\end{array}$ & $\begin{array}{l}\text { Determination of the fines } \\
\text { generation and mechanical } \\
\text { strength of the sorbent } \\
\text { material }\end{array}$ & $\begin{array}{l}\text { Direct measurement } \\
\text { Measurements of both particle crush } \\
\text { strength and abrasion resistance will } \\
\text { be required }\end{array}$ \\
\hline 14 & $\begin{array}{l}\text { Thermal stability } \\
\text { \% degradation in capacity } \\
\text { over time at selected } \\
\text { operating temperature }\end{array}$ & $\begin{array}{l}\text { Determine the extent of } \\
\text { capacity loss due to extended } \\
\text { exposure to operating } \\
\text { temperature. Determine the } \\
\text { extent of capacity loss due to } \\
\text { thermal cycling and } \\
\text { excursions }\end{array}$ & $\begin{array}{l}\text { Extended testing with thin-bed analysis } \\
\text { The sorbent should be exposed to the } \\
\text { operating temperature for extended } \\
\text { periods of time, and should experience } \\
\text { thermal cycling to simulate } \\
\text { regeneration of the sorbent. The } \\
\text { capacity should be measured after } \\
\text { thermal exposure by thin bed testing } \\
(\text { See Gap ID \#1) }\end{array}$ \\
\hline
\end{tabular}




\begin{tabular}{|c|c|c|c|}
\hline \# & Property & Specific requirements & Approach \\
\hline 15 & $\begin{array}{l}\text { Chemical stability } \\
\text { \% degradation in capacity } \\
\text { over time as a function of } \\
\text { other species present in gas } \\
\text { stream }\end{array}$ & $\begin{array}{l}\text { Determine the extent of } \\
\text { capacity loss due to extended } \\
\text { exposure to other species } \\
\text { present in the off-gas stream }\end{array}$ & $\begin{array}{l}\text { Extended testing with thin-bed analysis } \\
\text { Age sorbents for various lengths of } \\
\text { time to elevated levels of each of the } \\
\text { non-target species expected. } \\
\text { Determine Ru capacity and rates of } \\
\text { adsorption. Differences should be } \\
\text { attributable to aging and should be a } \\
\text { function of exposure time and non- } \\
\text { target species exposure }\end{array}$ \\
\hline 16 & $\begin{array}{l}\text { Reactivity } \\
\text { Compatibility as determined } \\
\text { by standardized } \\
\text { compatibility tables }\end{array}$ & $\begin{array}{l}\text { Confirmation that any } \\
\text { compatibility issues can be } \\
\text { avoided through selection of } \\
\text { materials of construction, } \\
\text { appropriate pretreatment of } \\
\text { gas stream, operational } \\
\text { envelope, etc. }\end{array}$ & Direct evaluation \\
\hline 17 & $\begin{array}{l}\text { Regeneration capacity } \\
\text { stability } \\
\text { Number of cycles and } \\
\Delta \text { mole/kg sorbent }\end{array}$ & $\begin{array}{l}\text { No. of cycles before } \\
\text { degrading to } 80 \% \text { of capacity } \\
\text { for the target element }\end{array}$ & $\begin{array}{l}\text { Extended testing with thin-bed analysis } \\
\text { Long-term, repeated testing of select } \\
\text { sorbent over multiple adsorption/ } \\
\text { desorption cycles if sorbent is to be } \\
\text { regenerated. N/A if single use }\end{array}$ \\
\hline 18 & $\begin{array}{l}\text { Desorption rate of } \mathbf{R u} \\
\mathrm{mol} / \mathrm{kg} \text { sorbent } / \mathrm{h}\end{array}$ & $\begin{array}{l}\text { Desorption rate as a function } \\
\text { of desorption temperature and } \\
\text { purge stream gas velocity }\end{array}$ & $\begin{array}{l}\text { Thin bed testing } \\
\text { (See Gap ID \#1) }\end{array}$ \\
\hline 19 & $\begin{array}{l}\text { Desorption of co-adsorbed } \\
\text { species } \\
\text { mol co-adsorbed species } \\
\text { retained/ } \mathrm{m}^{3} \text { sorbent }\end{array}$ & $\begin{array}{l}\text { Percentage of co-adsorbed } \\
\text { species desorbed during } \\
\text { selected regeneration } \\
\text { conditions }\end{array}$ & $\begin{array}{l}\text { Thin bed testing } \\
\text { (See Gap ID \#1) }\end{array}$ \\
\hline 20 & $\begin{array}{l}\text { Desorption rate of co- } \\
\text { adsorbed species } \\
\mathrm{mol} / \mathrm{kg} \text { sorbent } / \mathrm{h}\end{array}$ & $\begin{array}{l}\text { Desorption rate as a function } \\
\text { of desorption temperature and } \\
\text { purge stream gas velocity } \\
\text { Recommended experimental } \\
\text { ranges and potentially co- } \\
\text { adsorbing species are } \\
\text { provided in Gap ID \#3 }\end{array}$ & $\begin{array}{l}\text { Thin bed testing } \\
\text { (See Gap ID \#1) }\end{array}$ \\
\hline 21 & $\begin{array}{l}\text { Purity of Recovered Ru } \\
\text { mol impurity/kg Ru }\end{array}$ & $\begin{array}{l}\text { Prescribed by waste treatment } \\
\text { operation }\end{array}$ & ICP-MS of recovered phase \\
\hline 22 & Cooling time & Hours to cool from & Derived from heat capacity, thermal \\
\hline
\end{tabular}




\begin{tabular}{|c|c|c|c|}
\hline \# & Property & Specific requirements & Approach \\
\hline & $h$ & $\begin{array}{l}\text { regeneration temperature } \\
\left(\text { TBD }{ }^{\circ} \mathrm{C}\right) \text { to adsorbing } \\
\text { temperature }\left(30^{\circ} \mathrm{C}\right)\end{array}$ & conductivity, and bed design \\
\hline \multicolumn{4}{|c|}{ Metrics for system design and performance criterion } \\
\hline 23 & $\begin{array}{l}\text { Pressure drop } \\
P a / m \text { vs } m^{2} \text { column }\end{array}$ & $\begin{array}{l}\text { Size columns and sorbent size } \\
\text { for }<2.5 \mathrm{kPa} \text { pressure drop } \\
\text { based on expected gas flow } \\
\text { rates }\end{array}$ & $\begin{array}{l}\text { Direct measurement or scaled } \\
\text { derivation }\end{array}$ \\
\hline 24 & $\begin{array}{l}\text { Decontamination factor } \\
\text { (DF) } \\
{\left[\begin{array}{l}{[R u]_{\text {inlet }} /[R u]_{\text {outlet }}} \\
\text { (unitless) }\end{array}\right.}\end{array}$ & $\begin{array}{l}\text { DF data as function of } \\
\text { sorbent, Ru species, } \\
\text { temperature, concentration, } \\
\text { time, and bed depth } \\
\text { Recommended experimental } \\
\text { ranges and Ru species are } \\
\text { provided in Gap ID \#1 }\end{array}$ & $\begin{array}{l}\text { Deep bed testing with online } \\
\text { measurement of inlet and effluent Ru } \\
\text { concentrations } \\
\text { Test system must be able to hold a } \\
\text { deep bed of sorbent at given } \\
\text { temperature and expose sorbent to a } \\
\text { generated air stream containing water } \\
\text { (and any potentially co-adsorbed } \\
\text { species) at varying concentrations } \\
\text { within the specified concentration } \\
\text { range and gas velocity. Both inlet and } \\
\text { effluent gas streams must be assessed } \\
\text { for Ru concentration }\end{array}$ \\
\hline 25 & $\begin{array}{l}\text { Length of Mass Transfer } \\
\text { Zone } \\
m\end{array}$ & $\begin{array}{l}\text { Length of MTZ as a function } \\
\text { of gas velocity, target species } \\
\text { concentration, temperature, } \\
\text { and presence of co-absorbed } \\
\text { species shown to have impact } \\
\text { on total capacity or } \\
\text { adsorption rate of }>10 \% \\
\text { Recommended experimental } \\
\text { ranges and Ru species are } \\
\text { provided in Gap ID \#1 }\end{array}$ & $\begin{array}{l}\text { Deep bed tests with bed depth that } \\
\text { captures } 1.5 \text { times MTZ. Predictions } \\
\text { can be made from thin bed tests and } \\
\text { data may also be determined from DF } \\
\text { testing using deep beds } \\
\text { (Deep bed testing: Gap ID \#24) }\end{array}$ \\
\hline
\end{tabular}




\section{RUTHENIUM SOURCE TERM AND CHEMISTRY RELEVANT TO TRITIUM PRETREATMENT AND RUTHENIUM RETENTION}

The amounts of Ru isotopes in used PWR fuel having relatively high burnup are shown in Table 2, and the activity of the radioisotopes of $\mathrm{Ru}$ are shown in Table 3 . After 5 years of cooling, the only remaining radioisotope of $\mathrm{Ru}$ is practically ${ }^{106} \mathrm{Ru}$, with a mass of $\sim 7 \mathrm{~g} / \mathrm{tIHM}$ and activity of $\sim 23,300 \mathrm{Ci} / \mathrm{tIHM}$. The required decontamination factor (DF) for the removal of ${ }^{106} \mathrm{Ru}$ from the off-gas stream was estimated to be $3.04 \times 10^{7}$ in order to limit the contribution of $\mathrm{Ru}$ to the maximum exposed individual (MEI) to 0.025 mRem (Jubin, et al. 2014). The cited study estimated the required DFs for $5 \mathrm{y}$ cooled fuel, but as with ${ }^{85} \mathrm{Kr}$ and ${ }^{3} \mathrm{H}$, radioactive decay in aged fuel greatly diminishes (or possibly eliminates) the need to control the volatile specie. After $20 \mathrm{y}$ of cooling, the activity of ${ }^{106} \mathrm{Ru}$ is reduced to only $\sim 0.77 \mathrm{Ci} / \mathrm{tIHM}$. A full description of the potential abatement requirements for ${ }^{106} \mathrm{Ru}$ and other potentially volatile species is found in Jubin, et al. (2014).

Table 2. Mass of Ru isotopes in used nuclear fuel (g/tIHM) as a function of cooling time*

\begin{tabular}{|c|c|c|c|c|c|}
\hline \multirow{2}{*}{ Isotope } & \multirow{2}{*}{$\begin{array}{l}\mathbf{t}_{1 / 2} \\
\text { (d) }\end{array}$} & \multicolumn{4}{|c|}{ Cooling time (years) } \\
\hline & & $\mathbf{0}$ & 5 & 20 & 30 \\
\hline${ }^{100} \mathrm{Ru}$ & Stable & $2.45 \mathrm{E}+02$ & $2.45 \mathrm{E}+02$ & $2.45 \mathrm{E}+02$ & $2.45 \mathrm{E}+02$ \\
\hline${ }^{101} \mathrm{Ru}$ & Stable & $1.28 \mathrm{E}+03$ & $1.28 \mathrm{E}+03$ & $1.28 \mathrm{E}+03$ & $1.28 \mathrm{E}+03$ \\
\hline${ }^{102} \mathrm{Ru}$ & Stable & $1.32 \mathrm{E}+03$ & $1.32 \mathrm{E}+03$ & $1.32 \mathrm{E}+03$ & $1.32 \mathrm{E}+03$ \\
\hline${ }^{103} \mathrm{Ru}$ & 39.24 & $5.33 \mathrm{E}+01$ & 5.39E-13 & $0.00 \mathrm{E}+00$ & $0.00 \mathrm{E}+00$ \\
\hline${ }^{104} \mathrm{Ru}$ & Stable & $8.90 \mathrm{E}+02$ & $8.90 \mathrm{E}+02$ & $8.90 \mathrm{E}+02$ & $8.90 \mathrm{E}+02$ \\
\hline${ }^{105} \mathrm{Ru}$ & 0.185 & $1.89 \mathrm{E}-01$ & $0.00 \mathrm{E}+00$ & $0.00 \mathrm{E}+00$ & $0.00 \mathrm{E}+00$ \\
\hline${ }^{106} \mathrm{Ru}$ & 372.6 & $2.17 \mathrm{E}+02$ & $6.96 \mathrm{E}+00$ & $2.31 \mathrm{E}-04$ & $2.39 \mathrm{E}-07$ \\
\hline all $\mathbf{R u}$ & & $4.00 \mathrm{E}+03$ & $3.74 \mathrm{E}+03$ & $3.73 E+03$ & $3.73 E+03$ \\
\hline${ }^{106} \mathrm{Ru} / \mathrm{Ru}$ & $\%$ & $5.42 \mathrm{E}+00$ & $1.86 \mathrm{E}-01$ & $6.20 \mathrm{E}-06$ & $6.40 \mathrm{E}-09$ \\
\hline
\end{tabular}

* PWR fuel having burnup of $55 \mathrm{GWd} / \mathrm{MTIHM}$.

Table 3. Activity of Ru radioisotopes in used nuclear fuel (Ci/tIHM) as a function of cooling time*

\begin{tabular}{|c|c|c|c|c|c|}
\hline \multirow{2}{*}{ Isotope } & \multirow{2}{*}{$\begin{array}{c}\mathbf{t}_{1 / 2} \\
(\mathbf{d})\end{array}$} & \multicolumn{4}{|c|}{ Cooling time (years) } \\
\cline { 3 - 6 } & & $\mathbf{0}$ & $\mathbf{5}$ & $\mathbf{2 0}$ & $\mathbf{3 0}$ \\
\hline${ }^{103} \mathrm{Ru}$ & 39.24 & $1.73 \mathrm{E}+06$ & $1.74 \mathrm{E}-08$ & $0.00 \mathrm{E}+00$ & $0.00 \mathrm{E}+00$ \\
\hline${ }^{105} \mathrm{Ru}$ & 0.185 & $1.27 \mathrm{E}+06$ & $0.00 \mathrm{E}+00$ & $0.00 \mathrm{E}+00$ & $0.00 \mathrm{E}+00$ \\
\hline${ }^{106} \mathrm{Ru}$ & 372.6 & $7.25 \mathrm{E}+05$ & $2.33 \mathrm{E}+04$ & $7.74 \mathrm{E}-01$ & $8.00 \mathrm{E}-04$ \\
\hline
\end{tabular}

* PWR fuel having burnup of $55 \mathrm{GWd}$ /MTIHM. 


\subsection{Tritium Pretreatment Processes and Their Implications for $\mathbf{R u}$ Volatilization from Used Nuclear Fuel}

Either $\mathrm{O}_{2}$ (air) or $\mathrm{NO}_{2}$ can be used in TPT as the fuel oxidant to release the ${ }^{3} \mathrm{H}$ contained in the fuel meat into a small volume of gas for subsequent recovery. In standard TPT, the $\mathrm{UO}_{2}$ in the fuel is reacted with oxygen (as air or pure $\mathrm{O}_{2}$ ) to form $\mathrm{U}_{3} \mathrm{O}_{8}$. This results in the restructuring of crystalline $\mathrm{UO}_{2}$, accompanied by particle crumbling, and the release of most ${ }^{3} \mathrm{H}$; significant fractions of $\mathrm{Kr}, \mathrm{Xe}$, and carbon; and less than $10 \%$ of the iodine contained within the fuel. This process is conducted at temperatures ranging from 480 to $600{ }^{\circ} \mathrm{C}$. Higher temperatures increase the reaction rate and associated release rate of the volatile species.

Advanced TPT, utilizing $\mathrm{NO}_{2}$ as the oxidant, can be applied to chopped fuel or combined with chemical decladding. The process converts oxide fuel into a fine powder product that can be $\mathrm{U}_{3} \mathrm{O}_{8}, \mathrm{UO}_{3}$, or a nitrate depending on processing conditions. Advanced TPT also releases $\mathrm{Kr}, \mathrm{Xe}$, and carbon, and may result in a more quantitative iodine release than standard TPT. Advanced TPT is conducted at temperatures less than $400{ }^{\circ} \mathrm{C}$ (DelCul et al. 2016).

For standard TPT, it has been estimated that a fraction $(0.1 \%$ to $10 \%)$ of the $\mathrm{Ru}$ is released from the fuel as volatile $\mathrm{RuO}_{4}$ (Klein et al. 1980, Ronneau et al. 1995), of which about $20 \%$ to $30 \%$ becomes particulate once the gas stream cools, because $\mathrm{RuO}_{4}$ is thermodynamically unstable with respect to $\mathrm{RuO}_{2}$ at temperatures below $800{ }^{\circ} \mathrm{C}$ (Cains and Barnes 1991, Backman et al. 2005). During the coupled end-toend testing, there was no evidence of $\mathrm{Ru}$ reaching the off-gas capture and treatment systems, but the piping leading to the off-gas systems was not analyzed for $\mathrm{Ru}$ deposition, which prevented a determination of total $\mathrm{Ru}$ released during standard TPT. Although volatile $\mathrm{RuO}_{4}$ is not thermodynamically stable, its existence is exploited in the refining of $\mathrm{Ru}$, where aqueous soluble sodium ruthenate $\left(\mathrm{Na}_{2} \mathrm{RuO}_{4}\right)$ is treated with chlorine to release $\mathrm{RuO}_{4}(\mathrm{~g})$, which is recovered and further processed to prepare purified Ru metal (Lanam and Zysk 1982).

Few data are available to indicate how the use of $\mathrm{NO}_{2}$, a more powerful oxidant, affects the release of $\mathrm{Ru}$ during advanced TPT. Scoping studies have indicated that alternative oxidants (e.g., ozone and water vapor) may improve the release of selected volatile and semivolatile fission products either by further oxidizing the fuel and reducing its particle size or by producing more volatile chemical forms (DelCul et al. 2012). Results from calculations performed with the software HSC Chemistry version 9 (Outotec), described below, suggest the oxidation of $\mathrm{Ru}$ metal to $\mathrm{RuO}_{2}$ is unfavorable at low temperatures, but in practice, $\mathrm{Ru}$ metal oxidizes at measurable rates at temperatures $>450{ }^{\circ} \mathrm{C}$ (Lanam and Zysk 1982). Nevertheless, the lower temperature of the advanced pretreatment process could retard Ru release because slower kinetics are expected.

The examination of the source term, based on reaction free energies, was performed using HSC Chemistry. This software can evaluate the thermodynamics of reactions; from that, the reaction free energies for a system at equilibrium and standard conditions are determined. No kinetics can be evaluated with this software. Results verify that production of gaseous $\mathrm{RuO}_{3}$ or $\mathrm{RuO}_{4}$ from solid $\mathrm{RuO}_{2}$ is thermodynamically unfavored at temperatures ranging from 0 to $2000{ }^{\circ} \mathrm{C}$. Calculations indicate that direct conversion of the free metal to $\mathrm{RuO}_{4}$ in oxygen or $\mathrm{NO}_{2}$ is favored at temperatures below $900{ }^{\circ} \mathrm{C}$, but a lower energy state is obtained if the oxidation stops at $\mathrm{RuO}_{2}$.

Further, the reaction of $\mathrm{RuO}_{4}(\mathrm{~g})$ with $\mathrm{U}_{3} \mathrm{O}_{8}(\mathrm{~s})$ to produce $\mathrm{RuO}_{2}(\mathrm{~s})$ and $\mathrm{UO}_{3}(\mathrm{~s})$ is thermodynamically favored at all temperatures between 0 and $1000{ }^{\circ} \mathrm{C}$, which covers the likely range of the TPT process. The rate of the reaction is unknown. Therefore, whether any $\mathrm{RuO}_{4}(\mathrm{~g})$ emanates from the process depends on the rapidity with which $\mathrm{RuO}_{4}$ is produced and transported away and with which it reacts with the huge excess of available $\mathrm{U}_{3} \mathrm{O}_{8}(\mathrm{~s})$. 


\subsection{Speciation and Transport of Volatilized Ru}

A number of factors may impact the release of $\mathrm{Ru}$ from the fuel matrix through oxidation. The first factor to consider is the speciation of $\mathrm{Ru}$ in the fuel. A large fraction of the $\mathrm{Ru}$ is present in the fuel as an alloy containing Mo, Pd, Rh, and Tc (Kleykamp 1987, 1988) with the remainder dispersed in the $\mathrm{UO}_{2}$ matrix. The degree of this alloy's reactivity in the presence of oxygen is unknown. There are a number of stable $\mathrm{U}-\mathrm{Ru}$ intermetallic compounds (e.g., $\mathrm{U}_{2} \mathrm{Ru}, \mathrm{URu}, \mathrm{U}_{3} \mathrm{Ru}_{4}$, etc.) and $\mathrm{Ru}$ alloys (Rard 1985), but the production of these compounds from $\mathrm{UO}_{2}$ has not been fully characterized. Calculations with $\mathrm{HSC}$ Chemistry show that oxidation of $\mathrm{URu}_{3}$ to $\mathrm{UO}_{2}$ and $\mathrm{RuO}_{4}(\mathrm{~g})$ is favorable at temperatures above $0{ }^{\circ} \mathrm{C}$ to well over $1000{ }^{\circ} \mathrm{C}$. However, there is little expectation that such an intermetallic could form in the fuel because excess oxygen becomes available as the fission process takes place. Additionally, the overall reaction, $\mathrm{URu}_{3}+7 \mathrm{O}_{2}=\mathrm{UO}_{2}+3 \mathrm{RuO}_{4}$, likely proceeds by a multistep mechanism, meaning that several elementary steps are required to convert reactants to products. Further, $\mathrm{RuO}_{4}$ is a very strong oxidizing agent and gives up oxygen to any intermediate uranium compound that is not fully oxidized.

Thermodynamically stable $\mathrm{RuI}_{3}$, and $\mathrm{Ru}-\mathrm{Zr}$ compounds have been shown to exist (Rard 1985). Thus, when considering the mechanism by which $\mathrm{Ru}$ is released from the fuel and the consequent speciation in the gas phase, a better understanding of the Ru chemistry in the fuel is needed to calculate the Ru release during TPT. Thermochemical calculations with $\mathrm{HSC}$ Chemistry indicate that reactions between $\mathrm{RuO}_{2}$ (solid or gas) and oxygen-rich compounds (e.g., $\mathrm{Cs}_{2} \mathrm{UO}_{4}$ and $\mathrm{Cs}_{2} \mathrm{U}_{2} \mathrm{O}_{7}$ ) would not produce $\mathrm{RuO}_{4}$.

Readily available data on the interaction of $\mathrm{Ru}$ with $\mathrm{NO}_{2}$ in the gas phase is sparse. Although there are a number of ruthenium nitrosylnitrate compounds $\left\{\left[\operatorname{RuNO}\left(\mathrm{NO}_{3}\right)_{\mathrm{x}}\left(\mathrm{NO}_{2}\right)_{\mathrm{y}}(\mathrm{OH})_{\mathrm{z}}\left(\mathrm{H}_{2} \mathrm{O}\right)_{5-\mathrm{x}-\mathrm{y}-\mathrm{z}}\right]^{3-\mathrm{x}-\mathrm{y}-\mathrm{z}}\right\}$, these are most likely found in aqueous systems. The most common of the $\mathrm{Ru}$ compounds contain the $\mathrm{Ru}\left(\mathrm{NO}_{3}\right)^{3+}$ group, generally formed in aqueous nitric acid systems (Rard 1985). Igarachi et al. (1982) found that the presence of $\mathrm{NO}$ and $\mathrm{NO}_{2}$ reduces the proportion of $\mathrm{RuO}_{4}$ in the gas phase, making it more soluble in water, which could suggest the formation of a NO-bearing compound. Mun (2006) suggests the presence of a nitrosylruthenium compound and also that $\mathrm{NO}_{2}$ can react with $\mathrm{RuO}_{2}$ to form $\mathrm{RuO}_{4}$. The compounds $\mathrm{RuO}_{3}(\mathrm{OH})$ and $\mathrm{RuOH}$ might also exist.

A second factor that impacts the release of Ru into the gas phase during oxidation is the thermochemical favorability for release. Thermochemical calculations with HSC Chemistry show that oxidation of gaseous ruthenium dioxide $\left[\mathrm{RuO}_{2}(\mathrm{~g})\right]$ with oxygen to produce $\mathrm{RuO}_{4}(\mathrm{~g})$ is favorable at all temperatures between 0 and $2000{ }^{\circ} \mathrm{C}$. Thermodynamic stability is greater when $\mathrm{NO}_{2}$ is the oxidant. However, the vapor pressure of $\mathrm{RuO}_{2}(\mathrm{~s})$ is estimated to be negligible from 100 to $600{ }^{\circ} \mathrm{C}$. Because of the very small concentrations of $\mathrm{RuO}_{2}$ that could exist in the vapor phase, production of $\mathrm{RuO}_{4}(\mathrm{~g})$ by this route would seem to indicate that the vaporization and oxidation of $\mathrm{RuO}_{2}(\mathrm{~g})$ is extremely rapid, while the decomposition of $\mathrm{RuO}_{4}(\mathrm{~g})$ is, in relative terms, extremely slow. The slow decomposition of $\mathrm{RuO}_{4}(\mathrm{~g})$ at ambient temperatures is supported by the fact that $\mathrm{RuO}_{4}$ is persistent and can be recovered as a solid or liquid (Rard 1985). The tetroxide decomposes at temperatures above $500{ }^{\circ} \mathrm{C}$ (Mellor 1936). Oxidation of gaseous $\mathrm{RuO}_{2}$ may be the process by which $\mathrm{RuO}_{4}$ is produced in dry nuclear fuel TPT processes, and the extent of conversion is entirely controlled by the kinetics of the mechanism just discussed.

These results are in line with the literature, namely that $\mathrm{RuO}_{4}$ is the most produced and persistent $\mathrm{Ru}$ species in the gas phase at temperatures below $1000{ }^{\circ} \mathrm{C}$, even though the source term and total amount volatilized remain unclear. The $\mathrm{RuO}_{4}$ is expected to decompose slowly to $\mathrm{RuO}_{2}$ in the gas phase and on the stainless steel ductwork (Mun et al. 2006, Giordano et al. 2010). The volatile $\mathrm{RuO}_{4}$ decomposes to particulate $\mathrm{RuO}_{2}$ that is trapped in the scrubber and on HEPA filters. At air temperatures less than $700^{\circ} \mathrm{C}$, the gaseous concentration of $\mathrm{RuO}_{3}$ is expected to be negligible (Backman et al. 2005).

The third factor that may affect $\mathrm{Ru}$ presence in the gas phase is the presence and generation of particulates. It appears that the $\mathrm{Ru}$ is converted to a particulate that is relatively easily removed from the off-gas stream in the normally installed train of scrubbers, condensers, rough filters, and HEPA filters 
(Goles et al. 1981). However, the distribution of $\mathrm{Ru}$ between gas phase species and particulates is unknown.

Finally, it is unknown how the presence of ozone within the TPT system could affect Ru generation and stability in the gas phase. The intense radiation field that accompanies the head-end processing of highly radioactive UNF likely generates a steady state concentration of radiolysis products in the gas stream from the TPT atmosphere. This effect has been noted and partially studied as part of the severe reactor accident program (Mun et al. 2006; Pontillon et al. 2010; Giordano et al. 2010; Backman et al. 2005; Mun et al. 2008a, 2008b; Kajan et al. 2017a, 2017b; Singh et al. 2014). The projected radiolysis products in air are ozone $\left(\mathrm{O}_{3}\right)$, oxides of nitrogen $\left(\mathrm{NO}_{\mathrm{x}}\right)$, and free radicals $\left(\mathrm{O}^{-}, \mathrm{OH}^{-}\right.$, etc.) (Mun et al. 2008a). It has been documented that the presence of $\mathrm{O}_{3}$ in the gas stream, even at very low concentrations, can oxidize $\mathrm{RuO}_{2}$ to $\mathrm{RuO}_{4}$ and cause $\mathrm{Ru}$ to be transported (Mun et al. 2008a).

Also as part of the severe reactor accident program, the interactions between $\mathrm{RuO}_{4}$ and silver and iodine were studied (Kajan et al. 2017b, Kajan et al. 2016). The presence of both silver (as metal or as $\mathrm{AgNO}_{3}$ ) and $\mathrm{NO}_{2}$ significantly enhanced the transport of $\mathrm{Ru}$ as $\mathrm{RuO}_{4}$ (Kajan et al. 2017b). The presence of $\mathrm{RuO}_{4}$ oxidized iodine into volatile forms (Kajan et al. 2016). These findings indicate that $\mathrm{Ru}$ should be removed before iodine. The discussion above strongly suggests that the presence of radiolysis products in air or the air- $\mathrm{NO}_{2}$ mixture can cause some $\mathrm{RuO}_{2}$ to be oxidized to volatile $\mathrm{RuO}_{4}$ that could reach an iodine sorbent bed and increase the transport of iodine. These results highlight the importance of determining the effects of air radiolysis products on the performance of the Ru sorption system. These types of experiments are outside the scope of the proposed work but may be needed as the Ru removal design advances.

\section{POTENTIAL RUTHENIUM SORBENTS}

As $\mathrm{Ru}$ distribution between gas phase species and particulates is unknown, the degree of abatement provided by particulate filters is also unknown. HEPA filters have been shown to remove Ru-bearing particulates with a DF of $1 \times 10^{3}$ to $1 \times 10^{4}$ (Mineo et al. 2002), but they may be less effective against volatile $\mathrm{Ru}$ species, including $\mathrm{RuO}_{4}$. Thus, a removal operation for gaseous $\mathrm{Ru}$ is intended for placement within the off-gas treatment train to facilitate effective $\mathrm{Ru}$ abatement. The most commonly discussed $\mathrm{Ru}$ sorbents in the literature include silica gel, metal fibers or metal oxides, and liquid scrubbers. A solid sorbent would be most desirable for this application, and they are discussed in this section. Liquid scrubbing is useful for laboratory scoping tests and is discussed more fully in Section 6.

\subsection{Silica Gel}

It was recognized fairly early that volatile $\mathrm{Ru}$ could be trapped on silica gel at relatively low temperatures (Gill and Wisehart 1954). Later work suggested that a silica gel bed could be operated at moderate temperatures $\left(20\right.$ to $200{ }^{\circ} \mathrm{C}$ ) to remove $\mathrm{RuO}_{4}$ from moist air (Vujisić and Nikolić 1982, Klein et al. 1980). The consensus from the literature is that lower temperatures (approaching $25^{\circ} \mathrm{C}$ ) seem to best facilitate $\mathrm{Ru}$ adsorption on silica gel.

Silica gel is the most extensively studied $\mathrm{Ru}$ adsorber, and some studies have reported the capacity of silica gel for $\mathrm{Ru}$ in a flowing system. Ruthenium loadings on silica gel of $2.6 \mathrm{~kg} / \mathrm{m}^{3}$ are reported by Goossens (1991). Newby and Barnes (1975) report a Ru loading on silica gel of $4.8 \mathrm{~kg} / \mathrm{cm}^{3}$, but this number may reflect their upper analytical limit. Weisenburger and Seifert (1980) reported Ru loadings on silica gel of $3-4 \mathrm{~kg} / \mathrm{m}^{3}$ in the presence of steam.

Much of the reported work on silica gel was performed in a humid environment; such an environment does not translate directly to $\mathrm{Ru}$ adsorption from the off-gas of a dry TPT process. Nevertheless, two general observations were made from a review of literature. First, the adsorption of Ru on silica gel depends on the amount of water within the feed stream and within the silica bed. Several authors pretreated a silica bed with water prior to adsorption experiments to activate it (Newby and Barnes 1975, 
Vujisić and Nikolić 1982). As silica gel has some capacity for water, the presence of water/steam in the feed stream or adsorber bed could decrease the capacity of silica gel for Ru. However, water may promote the reduction of $\mathrm{RuO}_{4}$ to the less mobile $\mathrm{RuO}_{2}$ within the bed and decrease any potential migration of physisorbed $\mathrm{RuO}_{4}$ through the bed (Cains and Yewer 1985, Klein et al. 1980). Still unclear is whether silica gel has useable capacity for Ru in a dry standard TPT off-gas stream and whether it can retain $\mathrm{Ru}$ without water present. Klein et al. (1980) indicate that the physisorption of $\mathrm{RuO}_{4}$ onto silica gel from dry off-gas effectively creates a "delay bed" rather than a true Ru adsorber.

The second observation is that it is unknown how the presence of $\mathrm{NO}_{\mathrm{x}}$, such as would be present in an advanced TPT process, affects the adsorption of Ru on silica gel. Cains and Yewer (1985) reported that $\mathrm{NO}_{\mathrm{x}}$ resulted in higher DFs in their experimental system, and the presence of $\mathrm{NO}_{\mathrm{x}}$ decreased the amount of $\mathrm{Ru}$ released during desorption. Water was present in this test system. Klein et al. (1980) also indicated that $\mathrm{NO}_{\mathrm{x}}$ could increase system DF by facilitating $\mathrm{RuO}_{4}$ reduction to $\mathrm{RuO}_{2}$. However, this information is contradictory to that of Kepak et al. (1977), who stated that penetration of $\mathrm{RuO}_{4}$ through a silica gel bed increased substantially when $\mathrm{NO}_{\mathrm{x}}$ was present in the feed stream at several volume percent. In the case of the work by Kepak et al. (1977), the temperature of the silica gel beds was $200{ }^{\circ} \mathrm{C}$.

\subsection{Metal Fibers, Oxides, and Alloys}

Some research has been performed on the adsorption of $\mathrm{Ru}$ by metal fibers or metal oxides (Cains and Yewer 1985, Holm et al. 2009, Sakurai et al. 1985), but results suitable as the basis for an engineering design are limited. Calculations performed with HSC Chemistry indicate that at temperatures between 0 and $1000{ }^{\circ} \mathrm{C}$, oxidation of $\mathrm{Fe}, \mathrm{Ni}$, or $\mathrm{Cr}$ with $\mathrm{RuO}_{4}(\mathrm{~g})$ is thermodynamically very favorable. Reaction products are $\mathrm{RuO}_{2}(\mathrm{~s})$ and the oxides of $\mathrm{Fe}, \mathrm{Ni}$, and $\mathrm{Cr}$. In stainless steel alloys, the activities of these elements are lower than in the pure state, but stainless steel wool would likely be a good medium for reducing $\mathrm{RuO}_{4}$ while remaining impervious to the $\mathrm{NO}_{\mathrm{x}}$ present in the case of advanced TPT. Tests will be necessary to optimize the temperature for reducing and trapping the $\mathrm{Ru}$.

Newby and Barnes (1975) studied the adsorption of $\mathrm{Ru}$ from a flowing stream on a bed of ferric oxide. The DF of this system was found to increase with increasing bed temperature. In this work, the bed was held at $400{ }^{\circ} \mathrm{C}$. They report a Ru loading on stainless steel of $136 \mathrm{mg} / \mathrm{g}$, but this number may be an artifact of their upper analytical range.

Many studies examining the deposition of $\mathrm{Ru}$ on stainless steel provide insight into the speciation and the loading of $\mathrm{Ru}$ as a function of surface area and report if deposition is enhanced through specific experimental conditions (Sakurai et al. 1985, Mun et al. 2006, Mun et al. 2007a, Holm et al. 2009). However, practical engineering data remain unreported.

\subsection{Other Potential Sorbents}

Two other sorbents that may merit scoping-level testing for this application are alumina and glass. Newby and Barnes (1975) report a DF of 50 within their system with porous glass as the adsorbent. Mun et al. (2007a) and Holm et al. (2009) indicate that Ru loading on glass wool could be similar to that of stainless steel alloys. Holm et al. speculate that the deposition may be a function of surface area, rather than the specific material on which Ru deposits.

Vujisic and Nikolic (1982) considered alumina as a Ru sorbent and report loadings of 5-10 mg/m 3 . In Klein et al. (1977) a number of metal coupons were coated with $\mathrm{Ru}$ deposits, and the $\mathrm{Ru}$ coating on alumina coupons was reported to be extremely resistant to physical abrasion. An alumina sorbent could be operated at high temperature, perhaps the same as the TPT process temperature. 


\section{PROPOSED EXPERIMENTAL SYSTEM FOR EVALUATION OF RUTHENIUM SORBENTS}

The proposed experimental system consists of three parts: (1) a reliable method of generating the Ru species of interest, (2) an experimental apparatus to reliably test the proposed capture media, and (3) analysis methods suitable for the given application. These are treated in Sections 5 and 6. A test plan for determining key engineering parameters relating to $\mathrm{Ru}$ abatement by solid sorbents is described in Section 7.

\subsection{Proposed Ru Species Generation Systems}

As stated in Section 3.2, the predominant volatile species expected is $\mathrm{RuO}_{4}$; however, given the thermodynamic instability of this compound, the generation of a $\mathrm{RuO}_{4}$-bearing gas stream is not straightforward. Many of the $\mathrm{RuO}_{4}$ generation systems detailed in the literature rely on the evaporation or purging of highly oxidizing Ru-containing solutions. This is not viewed as ideal for this project given that the evaporation step would add some level of steam (water or acid vapor) to the test system. The steam would later have to be removed through a drying step that could significantly alter the Ru content of the simulated off-gas stream. Since either TPT process is carried out at temperatures less than $800{ }^{\circ} \mathrm{C}$, the temperature below which $\mathrm{RuO}_{3}$ is unstable with respect to $\mathrm{RuO}_{4}$, only techniques for $\mathrm{RuO}_{4}$ generation need be considered.

\subsubsection{Sparging or evaporation of oxidative solutions}

Several solution-based methods to produce metastable $\mathrm{RuO}_{4}(\mathrm{~g})$ have been summarized in the literature (e.g., Rard 1985, Mellor 1936), and most rely on the use of chlorine $\left(\mathrm{Cl}_{2}\right)$ to coax it from aqueous solution, for example, reaction of $\mathrm{Na}_{2} \mathrm{RuO}_{4}$ in aqueous solution by sparging with $\mathrm{Cl}_{2}$. The generation of volatile $\mathrm{RuO}_{3}$ and $\mathrm{RuO}_{4}$ from $\mathrm{Ru}$ and $\mathrm{RuO}_{2}$ has been carried out in simple systems consisting simply of a glass container with an acid solution of $\mathrm{RuCl}_{4}$ (Sasahira et al. 1996, Shin and Park 2003, Swider-Lyons et al. 2005, Voskresenskaya et al. 2014b, Vujisić and Nikolić 1982) or $\mathrm{RuO}_{3}$ (Mun et al. 2007a) to which an oxidizing agent (permanganate, potassium chlorate $\left[\mathrm{KClO}_{3}\right]$, or similar) is added. Generation of a continuous stream of $\mathrm{RuO}_{4}(\mathrm{~g})$ that is dried over $\mathrm{Mg}\left(\mathrm{ClO}_{4}\right)_{2}$ can be achieved by continuous addition of an oxidizing agent to an acid solution of $\mathrm{RuO}_{3}$.

To prepare a $\mathrm{RuO}_{4}$ generating system for simulation of TPT off-gas treatment systems, water vapor must be removed as neither of the TPT processes contain water. Since $\mathrm{RuO}_{4}$ is the primary gas in these generating systems, it is dried in a column packed with magnesium perchlorate $\left[\mathrm{Mg}\left(\mathrm{ClO}_{4}\right)_{2}\right]$. Magnesium perchlorate is used to both dry the gas and, because it is a strong oxidizing agent, keep the $\mathrm{Ru}$ as $\mathrm{RuO}_{4}$ (Mun et al. 2007a).

Both Cains and Yewer (1985) and Klein et al. (1980) generated $\mathrm{RuO}_{4}$ through evaporation/purging of $\mathrm{RuO}_{4}$ from a highly oxidizing solution. The system described by Cains and Yewer is shown in Figure 1. In both Cains and Yewer (1985) and Klein et al. (1980), $\mathrm{Ru}\left(\mathrm{RuCl}_{3}\right)$ was slowly fed into the oxidizing solution and, as $\mathrm{RuO}_{4}$ formed, it was removed in a continuous inert gas purge. In the case of Klein et al. (1980), the solution was $\mathrm{KIO}_{4}$ in $6 \mathrm{~N} \mathrm{H}_{2} \mathrm{SO}_{4}$ solution. They reported that they generated a stable evolution of Ru at 3 to $50 \mathrm{mg} / \mathrm{h}$ at a concentration of 50 to $830 \mathrm{mg} / \mathrm{m}^{3}$ (11 to $184 \mathrm{ppmv}$ ). 


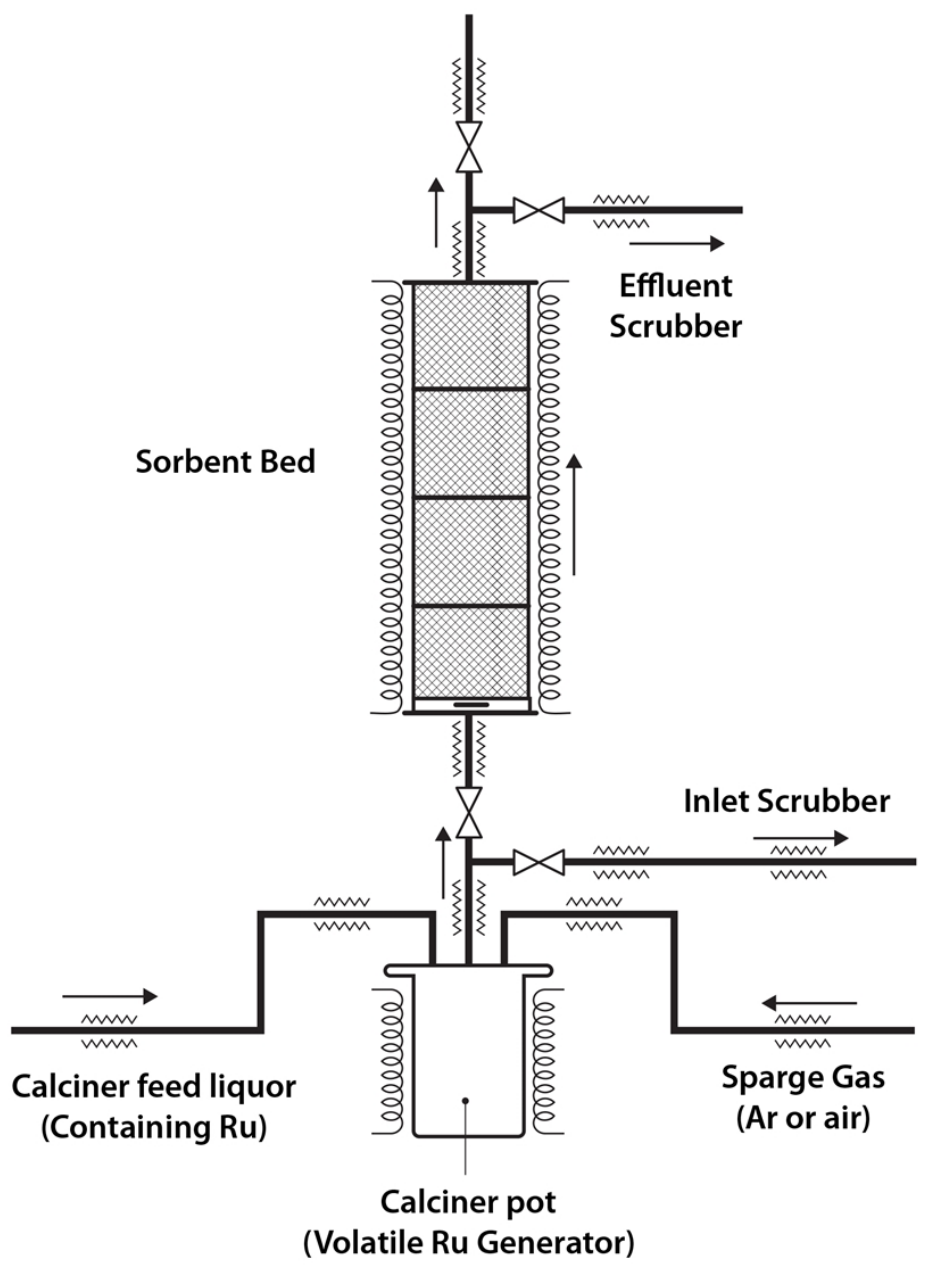

Figure 1. Evaporative/sparging system of the type described by Cains and Yewer (1985).

\subsubsection{Sublimation of $\mathrm{RuO}_{4}$ crystals}

Methods for preparing solid $\mathrm{RuO}_{4}$ crystals have been reported. Mellor (1936) describes one:

...recommended preparing the tetroxide of a high degree of purity by distilling at $40^{\circ}$ to $50^{\circ}$, in a current of air, an acidified solution of the mass obtained by fusing in a silver crucible a mixture of 1 part of finely divided ruthenium, 2 parts of potassium permanganate, and 20 parts of potassium hydroxide. The tetroxide condenses in a receiver, cooled with ice, in the form of long yellow needles.

This method, although useful for producing an air stream carrying $\mathrm{RuO}_{4}$, contains water vapor and the acid used for the acidification. Amundsen and Stern (1982) report essentially the same $\mathrm{RuO}_{4}$ preparation method as Mellor (1936) but indicate that $\mathrm{Cl}_{2}$ may be used instead of permanganate.

Holm et al. (2009) utilized $\mathrm{RuO}_{4}$ crystals in the chemical vapor deposition of $\mathrm{RuO}_{4}$ onto metal surfaces. The crystals were condensed on the exterior of a chilled sample vial and allowed to sublime into flowing $\mathrm{O}_{2}$ and deposit on metal coupons contained in the test system. This type of test system is shown in Figure 2 . 


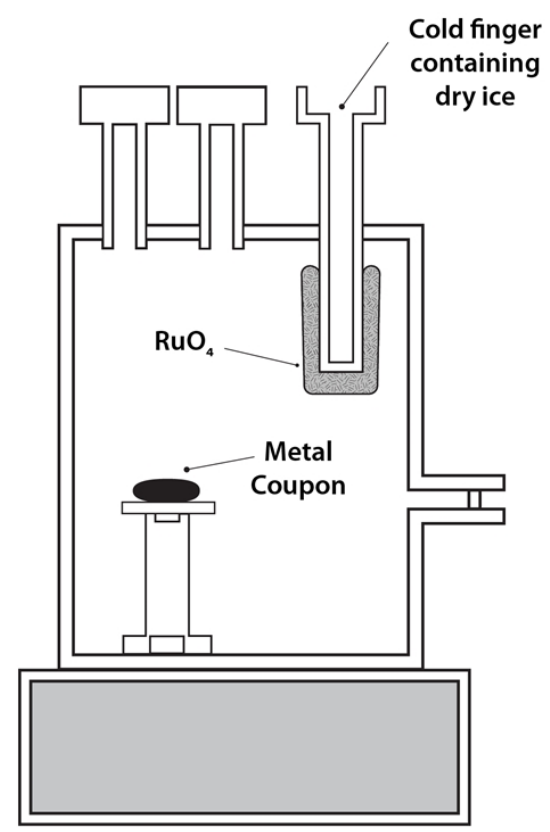

Figure 2. $\mathrm{RuO}_{4}$ crystalline generator of the type described by Holm et al. (2009).

\subsubsection{Oxidation of $\mathrm{Ru}$ or $\mathrm{RuO}_{2}$ solids}

Dry oxidation of $\mathrm{Ru}$ solids to generate $\mathrm{RuO}_{4}(\mathrm{~g})$ is not documented extensively in the literature. Backman et al. (2005) oxidized $\mathrm{RuO}_{2}$ powder with air in a two-zone tubular flow furnace. The temperature of the $\mathrm{RuO}_{2}$-containing zone was varied from 1227 to $1427{ }^{\circ} \mathrm{C}$ and the air flow was metered at $5 \mathrm{~L} / \mathrm{min}$. A similar concept was employed by Maas and Longo $(1979,1980)$ in which hydrated $\mathrm{RuO}_{2}$ was volatilized in $\mathrm{O}_{2}$ at $750{ }^{\circ} \mathrm{C}$. This type of experimental system is shown in Figure 3. 


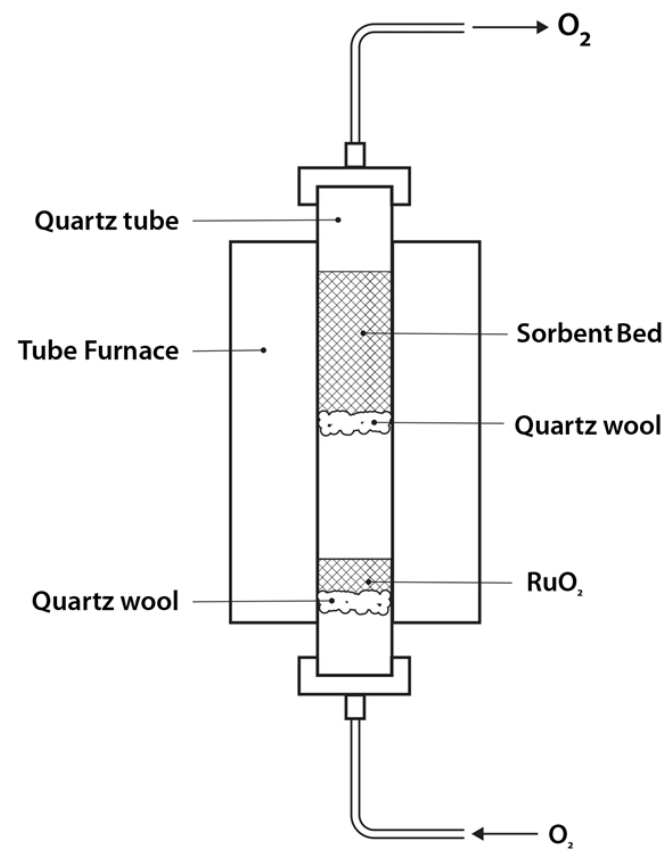

Figure 3. Dry volatilization system of the type described by Maas and Longo (1979).

As discussed in Section 3.1, calculations performed with HSC Chemistry verify that production of gaseous $\mathrm{RuO}_{4}$ from solid $\mathrm{RuO}_{2}$ is not thermodynamically favored at temperatures below $2000{ }^{\circ} \mathrm{C}$, which is in conflict with the generation methods described by Backman et al. (2005) and Holm et al. (2009). Calculations indicate that direct conversion of the free metal to $\mathrm{RuO}_{4}$ in oxygen or $\mathrm{NO}_{2}$ is favored at temperatures below $900{ }^{\circ} \mathrm{C}$, but a lower energy state is obtained if the oxidation stops at $\mathrm{RuO}_{2}$.

\subsection{Proposed Experimental Apparatus}

Work on $\mathrm{Ru}$ abatement system designs performed in the engineering evaluation of an integrated off-gas system for the head-end off-gas stream of a reprocessing facility (Jubin et al. 2016) determined that further characterization of both metal- and silica-based sorbents would be advantageous in refining future $\mathrm{Ru}$ abatement system designs. The literature reviews and calculations detailed in Sections 3 and 4 provided a basis for the design of an experimental system, an analytical method, and a test plan, which are documented in the remaining sections of this report. The difficulties in handling Ru-bearing gas streams, from both safety and practicality perspectives, drove the decision to propose a very simple test system and test design.

\subsubsection{General experimental considerations}

Care must be exercised in the handling of $\mathrm{RuO}_{4}(\mathrm{~g})$, as it tends to decompose on many surfaces. Those surfaces that appear to have the least tendency to act as a decomposition site for $\mathrm{RuO}_{4}$ are alumina and Teflon (polytetrafluoroethylene, or PTFE). Although PTFE has been used in experiments (Mun et al. 2007a, 2007b), a glassier form of Teflon, perfluoroalkoxy alkanes (PFA), should be considered. Teflon can be used at temperatures up to about $250^{\circ} \mathrm{C}$. Regardless of the materials of construction, some decomposition of $\mathrm{RuO}_{4}$ to $\mathrm{RuO}_{2}$ is expected, and this must be taken into account when assessing the experimental results.

Care must also be taken with respect to the partial pressures of $\mathrm{RuO}_{4}$, given the potential for explosive decomposition of $\mathrm{RuO}_{4}$ to $\mathrm{RuO}_{2}$. Eichler et al. (1992) demonstrated that as the concentrations of $\mathrm{Ru}$ decrease, the thermodynamic stabilities of the vapor and solid species change, favoring the stability of 
solid $\mathrm{RuO}_{3}$. They point out that the decomposition temperature for $\mathrm{RuO}_{3}(\mathrm{~g})$ could fall below $700{ }^{\circ} \mathrm{C}$. This could lead to enhanced transport of Ru in the silca gel sorption bed. Thus, the test matrix should include a wide range of $\mathrm{Ru}$ concentrations of probable species in the TPT off-gas streams.

\subsubsection{Proposed test system}

Designers of a test system for Ru abatement studies must first determine the method by which the Rubearing gas stream will be generated. The evaporative approach described in Section 5.1 is the most extensively documented method for generating gaseous $\mathrm{RuO}_{4}$; however, this approach adds moisture to the gas stream. One of the large data gaps related to $\mathrm{Ru}$ capture by the sorbents reviewed is their performance in a dry stream, such as would be generated by TPT. Therefore, the evaporative method is not ideal for use in the experimental application described here. Although a gas stream could be dried after $\mathrm{Ru}$ generation and prior to entering the sorbent test bed, it is likely that Ru would be lost during this drying step and that characterization of the loss would add experimental uncertainty to the results.

The generation of $\mathrm{Ru}$ from $\mathrm{RuO}_{4}$ crystals was also considered, but the mass of $\mathrm{RuO}_{4}$ crystals required to generate a Ru-bearing gas stream would be larger than can be safely handled without specialized facilities. Solid-phase $\mathrm{RuO}_{4}$ can decompose explosively at temperatures within the range of interest for this application.

Given the concerns described here, the generation of a Ru-bearing stream from Ru metal exposed to air or oxygen appears to be the easiest method to implement for this application. Figure 4 shows a diagram of the proposed test system. Ruthenium metal is held in a horizontal tube furnace at high temperatures (likely $>500{ }^{\circ} \mathrm{C}$ ) through which $\mathrm{O}_{2}$ or air will be metered. This configuration is expected to volatilize some of the Ru metal. The test beds are to be connected to the tube furnace such that the Ru-bearing gas stream remains in the heated zone and is immediately passed through the sorbent bed. Upon exiting the sorbent bed, any $\mathrm{RuO}_{4}$ not absorbed by the sorbent bed is removed in an aqueous scrubber. All materials of construction are quartz, with the temperature of both the tube furnace and the sorbent bed carefully controlled to avoid unexpected $\mathrm{Ru}$ deposition within the test system. The mass of the $\mathrm{Ru}$ metal is measured before and after each experiment, allowing determination of the expected gas-phase concentration for each experiment.

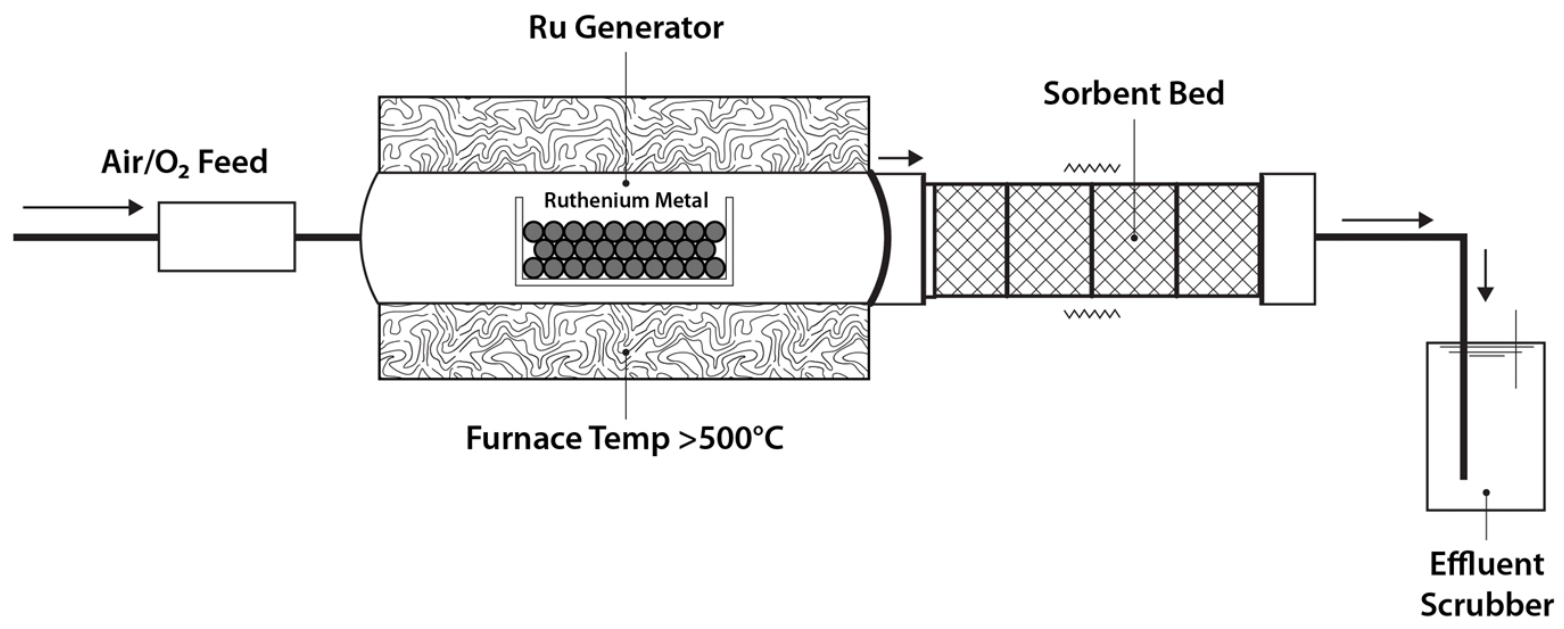

Figure 4. Proposed Ru test system. 


\section{PROPOSED ANALYSIS METHODS}

The tests proposed here support the use of various analytical techniques. Quantification of the volatilized solid $\mathrm{Ru}\left(\mathrm{RuO}_{4}\right.$ crystal or $\left.\mathrm{RuO}_{2}\right)$ is accomplished by measuring the mass of the source $\left(\mathrm{Ru}\right.$ metal or $\left.\mathrm{RuO}_{2}\right)$ before and after the experiment. The rate at which the $\mathrm{Ru}$ is volatilized is calculated from the mass loss and the time of the experiment. It is assumed that mass change due to $\mathrm{Ru}$ oxidation during the experiment is negligible in comparison with the amount volatilized.

Ruthenium trapped in the bubbler solution $(\mathrm{KOH})$ has been determined after quantitatively precipitating $\mathrm{Ru}$ with the addition of ethyl alcohol to the $\mathrm{KOH}$ and centrifuging the precipitated $\mathrm{Ru}$; the precipitated $\mathrm{Ru}$ can be dissolved and determined with ICP-MS (Holm et al. 2009, Kajan et al. 2016, Mun et al. 2007b).

The $\mathrm{Ru}$ on the $\mathrm{Ru}$ sorbent can be characterized with solid-state analyses (SEM) and chemical analyses with dissolution followed with ICP-MS. Neutron activation analyses can also be used.

\subsection{Liquid Scrubbers}

Wet scrubbing of the off-gas streams has been reported to have DF values of 10 to $10^{4}$ (Klein et al. 1980, Kitamura et al. 1993, Oma and Nelson 1981). For the tests to be performed in this study, a $1 \mathrm{molal} \mathrm{KOH}$ solution and two scrubbers in series is recommended. Each of these scrubbers has a DF of about 1000. The Ru captured in the scrubbers can be measured with ICP-MS.

Alternatively, a scrubber solution of $\mathrm{NaOH}-\mathrm{NaOCl}$ could be used and the perruthenate peak at $385 \mathrm{~nm}$ monitored as an online method. Separation and spectrophotometric characterization of the dissolved $\mathrm{Ru}$ species is possible (Kuchekar et al. 2015), but analyses of the solutions with ICP-MS is a more developed method.

\section{RECOMMENDATIONS}

A proof-of-principle test matrix is proposed here, based on the literature review of $\mathrm{Ru}$ gaseous behavior and $\mathrm{Ru}$ abatement technologies. This test matrix provides insight into the behavior of $\mathrm{Ru}$ in laboratory test systems and generates initial results for Ru deposition on two solid sorbents. The test system, as described in Sections 5 and 6, consists of a tube furnace in which $\mathrm{Ru}$ metal is oxidized to $\mathrm{RuO}_{4}$, a sorbent bed directly adjacent to the tube furnace, and an aqueous scrubber to capture any gaseous $\mathrm{RuO}_{4}$ passing through the sorbent bed. The test system is constructed of single-use glass parts so that no residual $\mathrm{Ru}$ is carried over from one experiment to the next. The glass components may be leached to assess residual $\mathrm{Ru}$. Dissolution of the $\mathrm{RuO}_{2}$ deposits can be accomplished with a solution of $\mathrm{KOH}(0.2$ molal $)$ and $\mathrm{K}_{2} \mathrm{~S}_{2} \mathrm{O}_{8}$ (18.5 mmolal) followed by $\mathrm{Ru}$ analyses with ICP-MS. Gill and Wisehart (1954) report that the $\mathrm{RuO}_{2}$ deposited on silica gel can be quantitatively removed with hot concentrated (12 molal) $\mathrm{HCl}$.

\subsection{Characterization of Ru Generation and Deposition within the Test System}

Ruthenium is expected to be deposited throughout the test system. To quantify Ru loss to the test system, baseline testing is performed with the fully assembled test system and no emplaced sorbent. A Ru-bearing gas stream is generated by flowing $\mathrm{O}_{2}$ or air over Ru metal at elevated temperature (likely $>500{ }^{\circ} \mathrm{C}$ ) and sending it through the empty sorbent holder. The amount of $\mathrm{Ru}$ recovered from the effluent in the liquid scrubbers (described in Section 6.1) is compared to the amount of volatilized $\mathrm{Ru}$, as measured by mass loss of $\mathrm{Ru}$ contained in the generation cell. The difference represents the amount of $\mathrm{Ru}$ lost to the test system. As Ru deposition is dependent upon experimental conditions, testing to quantify deposition of $\mathrm{Ru}$ within the system should be replicated for each expected sorbent test condition. 
The liquid scrubbers are used both to quantify Ru deposition within the test system and to characterize the $\mathrm{Ru}$ generation method. After exiting the sorbent holder, the gas stream goes through $\mathrm{NaOH}-\mathrm{NaOCl}$ bubblers; aliquots of the solutions are taken on a time schedule and submitted for analysis. This testing provides insight into the stability of the Ru concentration in the gas stream.

Although the scrubber solutions are expected to be analyzed by ICP-MS, $\mathrm{RuO}_{4}$ forms an orange complex in $\mathrm{NaOH}$. The extinction coefficient for this complex is not adequately documented. Beer's Law is used to determine the lower limit of quantitation and if UV-Vis spectroscopy is found to be sufficiently sensitive, it can be used for monitoring the effluent stream in sorbent testing experiments. This could provide nearly real-time estimation of breakthrough times for the sorbents investigated.

\subsection{Adsorption of Ru by Metal Sorbent}

This test will characterize the adsorption of Ru by stainless steel wool at temperatures of 150 and $300{ }^{\circ} \mathrm{C}$. In the literature, porous stainless steel disks as Ru filters were tested (Klein et al. 1980). Stainless steel in general has been found to catalyze the transformation of $\mathrm{RuO}_{4}$ to $\mathrm{RuO}_{2}$ and $\mathrm{O}_{2}$. In the removal of $\mathrm{Ru}$, a high-surface-area medium, such as stainless steel wool, could provide sufficient surface area at low pressure drop to result in high Ru removal efficiency.

Testing exposes the stainless steel wool to a Ru-bearing stream for up to 48 hours. Periodic sampling of the effluent scrubber allows for estimation of Ru breakthrough time through the sorbent bed. The sorbent bed, after being contacted with $\mathrm{Ru}$, is purged with dry air or $\mathrm{O}_{2}$ to ensure full removal of any physisorbed $\mathrm{Ru}$ within the sorbent bed. It is unlikely that $\mathrm{Ru}$ will be desorbed from the sorbent bed, but if so, it is collected in the aqueous scrubber. Following desorption, the bed is removed in sections to allow analysis of Ru loading and estimation of the mass transfer zone depth.

\subsection{Adsorption of Ru by Silica Gel}

This test is used to characterize the adsorption of Ru by silica gel at a temperature of $150{ }^{\circ} \mathrm{C}$. As stated previously, there is some discrepancy in the literature as to the usefulness of silica gel in Ru abatement, but lower temperatures should facilitate $\mathrm{Ru}$ deposition within the sorbent media, with higher temperatures promoting continued volatility and mobility of $\mathrm{RuO}_{4}$ within the system.

Silica gel can be used as received or after washing and heat treating (drying) at $150{ }^{\circ} \mathrm{C}$. Testing then proceeds similarly to that described in Section 7.2. Ruthenium loading on silica gel can be determined directly from neutron activation analysis, but it can also be dissolved for ICP-MS analysis by either a solution of $\mathrm{KOH}(0.2$ molal $)$ and $\mathrm{K}_{2} \mathrm{~S}_{2} \mathrm{O}_{8}(18.5$ mmolal $)$ or hot concentrated $\mathrm{HCl}$.

\subsection{Data Obtained}

This series of initial testing is intended to provide (1) Ru breakthrough time and Ru loading capacity of metal mesh in a dry stream, (2) Ru breakthrough time and Ru loading capacity of silica gel in a dry stream, and (3) Ru desorption from silica gel as a function of time ( $\mathrm{mg} \mathrm{Hg}^{-1} \mathrm{~g}^{-1}$ loaded silica). In addition, information such as the length of the mass transfer zone may be obtained through successful leaching of the sorbent beds. Finally, any experimental data gathered on $\mathrm{Ru}$ quantitation by either UV-Vis spectroscopy or neutron activation analysis may augment the literature available on the subject of $\mathrm{Ru}$ analysis. Much of the information intended to be collected from this testing will be directly useful in the refinement of $\mathrm{Ru}$ abatement system designs such as those included in the engineering evaluation of an integrated off-gas system for the head-end off-gas stream of a reprocessing facility (Jubin et al. 2016). 


\section{REFERENCES}

Amundsen, AR, and EW Stern. 1982. "Platinum Group Metals, Compounds," pp. 254-277 in KirkOthmer Encyclopedia of Chemical Technology, vol 18, $3^{\text {rd }}$ ed., Wiley-Interscience, New York.

Backman, U, M Lipponen, A Auvinen, U Tapper, R Zilliacus, and JK Jokiniemi. 2005. "On the Transport and Speciation of Ruthenium in High Temperature Oxidising Conditions," Radiochimica Acta 93(5):297-304. 10.1524/ract.93.5.297.64280.

Cadieux, JR, and JA Stone. 1980. "Voloxidation and dissolution of irradiated plutonium recycle fuels," No. DP-MS-80-10.

Cains, PW, and SJ Barnes. 1991. "Deposition of Volatilized Ruthenium on Stainless-Steels." Journal of Nuclear Materials 186(1):83-86. 10.1016/0022-3115(91)90356-c.

Cains, PW, and KC Yewer. 1985. "Volatile Ruthenium Trapping on Silica Gel and Solid Catalysts," pp. 1361-1377 in Proceedings of the 18th DOE Nuclear Air Cleaning Conference, Harvard Air Cleaning Laboratory, Cambridge, MA.

DelCul, GD, JA Johnson, RD Hunt, ED Collins, BB Spencer, and RT Jubin. 2012. “Conceptual Design of a Simplified Head-End Process for Recycling of Used Nuclear Fuel,” ANS 2012 Annual Meeting, Chicago, June.

DelCul, GD, JA Johnson, BB Spencer, RD Hunt, and RT Jubin. 2016. "Dry Pretreatment of Used Nuclear Fuel for Tritium Removal: A Review," Transactions of the American Nuclear Society 114:91-92, New Orleans, Louisiana, June 12-16.

DOE. 2003. Nuclear Air Cleaning Handbook, DOE-HDBK-1169-2003, US Department of Energy, Washington, DC.

Eichler, B, F Zude, W Fan, N Trautmann, and G Herrmann. 1992. "Volatilization and Deposition of Ruthenium Oxides in a Temperature Gradient Tube," Radiochimica Acta 56:133-140.

Gill, WE, and DE Wisehart. 1954. A Study of Certain Properties of Ruthenium Compounds Found in the Redox Process, report HW-32175, Hanford Atomic Products Operation, Richland, WA.

Giordano, P, A Auvinen, G Brillant, J Colombani, N Davidovich, R Dickson, T Haste, T Karkela, JS Lamy, C Mun, D Ohai, Y Pontillon, M Steinbruck, and N Ver. 2010. "Recent Advances in Understanding Ruthenium Behaviour under Air-Ingress Conditions During a PWR Severe Accident," Progress in Nuclear Energy 52(1):109-19. 10.1016/j.pnucene.2009.09.011.

Goles, RW, FP Brauer, DC Hamilton, and JE Fager. 1981. "Nuclear Waste Vitrificaiton Effluent," pp. 891-910 in Proceedings of the $16^{\text {th }}$ DOE Nuclear Air Cleaning Conference (CONF-801038), The Harvard Air Cleaning Laboratory, Cambridge, MA.

Goode, JH. 1973. Voloxidation: Removal of Volatile Fission Products from Spent LMFBR Fuels, report ORNL-TM-3723, Oak Ridge National Laboratory, Oak Ridge, TN.

Goode, JH, and RG Stacy. 1980. Voloxidation and Dissolution of Irradiated (Th, U) $O_{2}$, report ORNL/TM6643, Oak Ridge National Laboratory, Oak Ridge, TN.

Goossens, WRA, GG Eichholz, and DW Tedder, eds. 1991. "Treatment of Gaseous Effluents at Nuclear Facilities," Radioactive Waste Management Handbook Volume 2, Harwood Academic Publishers, Newark, NJ.

Holm, J, H Glanneskog, and C Ekberg. 2009. "Deposition of $\mathrm{RuO}_{4}$ on Various Surfaces in a Nuclear Reactor Containment," Journal of Nuclear Materials 392(1):55-62. 
Igarashi, H, K Kato, and T Takahashi. 1992. "Absorption of Gaseous Ruthenium into Water," Radiochimica Acta 57(1):51-55.

Johnson, DR, and JA Stone. 1977. "Light Water Reactor Fuel Reprocessing: Dissolution Studies of Voloxidized Fuel," in ANS - The Back End of the LWR Fuel Cycle, report DP-MS-77-77.

Jubin, R, N Soelberg, D Strachan, and G Ilas. 2011. Assessments and Options for Removal and Immobilization of Volatile Radionuclides from the Processing of Used Nuclear Fuel, report FCR\&D-SWF-2011-000305, Oak Ridge National Laboratory, Oak Ridge, TN.

Jubin, R, N Soelberg, D Strachan, and G Ilas. 2012a. Fuel Age Impacts on Gaseous Fission Product Capture During Separations, report FCRD-SWF-2012-000089, PNNL-22550, Oak Ridge National Laboratory, Oak Ridge, TN.

Jubin, RT, NR Soelberg, DM Strachan, and G Ilas. 2012b. Position Paper on Practicable Performance Criteria for the Removal Efficiency of Volatile Radionuclides, report FCRD-SWF-2012-000091, Oak Ridge National Laboratory, Oak Ridge, TN.

Jubin, R, N Soelberg, and D Strachan. 2013. Iodine Pathways and Off-Gas Stream Characteristics for Aqueous Reprocessing Plants - A Literature Survey and Assessment, report FCRD-SWF-2013000308 (ORNL/LTR-2013/383, INL/EXT-13-30119, PNNL-22885), Oak Ridge National Laboratory, Oak Ridge, TN.

Jubin, RT, DM Strachan, G Ilas, BB Spencer, and NR Soelberg. 2014. Radioactive Semivolatiles in Nuclear Fuel Reprocessing, report FCRD-SWF-2014-000601 (ORNL/LTR-2014/354), Oak Ridge National Laboratory, Oak Ridge, TN.

Jubin, RT, JA Jordan, BB Spencer, NR Soelberg, AK Welty, M Greenhalgh, DM Strachan, and PK Thallapally. 2016. Engineering Evaluation of an Integrated Off-Gas Treatment System for Used Nuclear Fuel Reprocessing Facilities, report FCRD-MRWFD-2016-000313, UT-Battelle, LLC, Oak Ridge National Laboratory, Oak Ridge, TN.

Jubin, RT, SH Bruffey, JA Jordan, BB Spencer, AK Welty, NR Soelberg, and M Greenhalgh. 2017. Data Requirements and Test System Needs for Development of an Integrated Off-Gas Treatment System, report NTRD-MRWFD-2017-000422, UT-Battelle, LLC, Oak Ridge National Laboratory, Oak Ridge, TN.

Kajan, I, S Tietze, and C Ekberg. 2016. "Interaction of Ruthenium Tetroxide with Iodine-Covered Surfaces of Materials in Nuclear Reactor Containment Building," Journal of Nuclear Science and Technology (Abingdon, UK) 53(11):1889-98. 10.1080/00223131.2016.1174627.

Kajan, I, T Kärkelä, A Auvinen, and C Ekberg. 2017a. "Effect of Nitrogen Compounds on Transport of Ruthenium through the RCS," Journal of Radioanalytical and Nuclear Chemistry 311(3):2097-109. 10.1007/s10967-017-5172-7.

Kajan, I, T Kärkelä, U Tapper, L-S Johansson, M Gouëllo, H Ramebäck, S Holmgren, A Auvinen, and C Ekberg. 2017b. "Impact of Ag and NOx Compounds on the Transport of Ruthenium in the Primary Circuit of Nuclear Power Plant in a Severe Accident," Annals of Nuclear Energy 100(Part_2):9-19. 10.1016/j.anucene.2016.10.008.

Kepak, F, J Razga, and E Uher. 1977. "Radioactive aerosols and gases in nuclear facilities," pp. 11-21 in Nukleon 6.

Kitamura, M, K Shirato, and K Arai. 1993. "Experimental Study on the Volatile Ruthenium Decontamination Factor of the Perforated Plate Column Scrubber," pp. 254-261 in Proceedings of the 22 $2^{\text {nd }}$ DOE/NRC Nuclear Air Cleaning and Treatment Conference (NUREG/CP-130, CONF9020823), The Harvard Air Cleaning Laboratory, Cambridge, MA. 
Klein, R, and A Shih. 1977. "Chemisorption and Decomposition of Nitric Oxide on Ruthenium," Surface Science 69(2):403-427.

Klein, M, M De Smet, WRA Goossens, and LH Baetsle. 1980. "Filtration and Capture of Semivolatile Nuclides," pp. 91-100 in Proceedings of the International Symposium on the Management of Gaseous Wastes from Nuclear Facilities, International Atomic Energy Agency, Vienna.

Kleykamp, H. 1987. "Composition after Dissolution in $\mathrm{HNO}_{3}$ of the Residue of KNK-II-I Fuel," Atomwirtschaft-Atomtechnik 32(5):235-36.

Kleykamp, H. 1988. "The Chemical-State of the Fission-Products in Oxide Fuels at Different Stages of the Nuclear-Fuel Cycle," Nuclear Technology 80(3):412-22.

Kuchekar, SR, YS Shelar, RJ Bhor, MA Anuse, and RM Naval. 2015. "Separation and Spectrophotometric Determination of Osmium(IV) and Ruthenium(III) with $O$-Methoxyphenyl Thiourea as Chromogenic Legand: Sequential Separation of Osmium(IV), Ruthenium(III), and Platinum(IV)," Separation Science and Technology 50(8):1190-201.

Lanam, RD, and ED Zysk. 1982. "Platinum Group Metals," pp. 228-253 in Kirk-Othmer Encyclopedia of Chemical Technology, vol 18, $3^{\text {rd }}$ ed., Wiley-Interscience, New York.

Maas, ET, Jr. and JM Longo. 1979. "Confinement of Volatilized Ruthenium Oxides," Scientific Basis for Nuclear Waste Management 1:487-90.

Maas, ET, Jr. and JM Longo. 1980. "Confinement of Ruthenium Oxides Volatilized During Nuclear Fuels Reprocessing," Nuclear Technology 47(3):451-56.

Mellor, JW. 1936. A Comprehensive Treatise on Inorganic and Theoretical Chemistry, Vol XV, Longmans, Green and Co., London.

Mineo, H, M Gotoh, M Iizuka, S Fujisaki, and G Uchiyama. 2002. "A Simple Model Predicting Iodine Profile in a Packed Bed of Silica-Gel Impregnated with Silver Nitrate," Journal of Nuclear Science and Technology 39(3):241-47.

Mun, C, L Cantrel, and C Madic. 2006. "Review of Literature on Ruthenium Behavior in Nuclear Power Plant Severe Accidents," Nuclear Technology 156(3):332-46.

Mun, C, L Cantrel, and C Madic. 2007a. "Study of $\mathrm{RuO}_{4}$ Decomposition in Dry and Moist Air," Radiochimica Acta 95(11):643-56.

Mun, C, JJ Ehrhardt, J Lambert, and C Madic. 2007b. "XPS Investigations of Ruthenium Deposited onto Representative Inner Surfaces of Nuclear Reactor Containment Buildings," Applied Surface Science 253(18):7613-21. 10.1016/j.apsusc.2007.03.071.

Mun, C, L Cantrel, and C Madic. 2008a. "Oxidation of Ruthenium Oxide Deposits by Ozone," Radiochimica Acta 96(6):375-84. 10.1524/ract.2008.1501.

Mun, C, L Cantrel, and C Madic. 2008b. "Radiolytic Oxidation of Ruthenium Oxide Deposits," Nuclear Technology 164(2):245-54.

Newby, BJ, and VH Barnes. 1975. Volatile Ruthenium Removal from Calciner Off-Gas Using Solid Sorbents, report ICP--1078, Allied Chemical Corp., Idaho Falls, ID.

Oma, KH, and TA Nelson. 1981. Behavior of Selected Contaminants in Liquid-Fed Ceramic Melter Waste-Vitrification Off Gas, pp. 911-928 in Proceedings of the $16^{\text {th }}$ DOE Nuclear Air Cleaning Conference (CONF-801038), The Harvard Air Cleaning Laboratory, Cambridge, MA.

Outotec. Chemical Reaction and Equilibrium HSC software version 9. Pori, Finland. 
Pontillon, Y, G Ducros, and PP Malgouyres. 2010. "Behaviour of Fission Products under Severe PWR Accident Conditions VERCORS Experimental Programme-Part 1: General Description of the Programme," Nuclear Engineering and Design 240(7):1843-52. 10.1016/j.nucengdes.2009.06.028.

Rard, JA. 1985. "Chemistry and Thermodynamics of Ruthenium and Some of Its Inorganic Compounds and Aqueous Species," Chemical Reviews 85(1), February.

Ronneau, C, J Cara, and A Rimskikorsakov. 1995. "Oxidation-Enhanced Emission of Ruthenium from Nuclear Fuel," Journal of Environmental Radioactivity 26(1):63-70.

Sakurai, T, Y Hinatsu, A Takahashi, and G Fujisawa. 1985. "Adsorption of Ruthenium Tetroxide on Metal-Surfaces," Journal of Physical Chemistry 89(10):1892-96. 10.1021/j100256a016.

Sasahira, A, T Hoshikawa, M Kamoshida, and F Kawamura. 1996. "Transfer of Ruthenium from a Simulated Reprocessing Solution to Gas Phase During a Continuous Distillation," Journal of Nuclear Science and Technology 33(10):753-57.

Shin, JM, and JJ Park. 2003. "Trapping Characteristics of Volatile Ruthenium Oxides by $\mathrm{Y}_{2} \mathrm{O}_{3}$ Filter," Korean Journal of Chemical Engineering 20(1):145-50. 10.1007/bf02697200.

Singh, K, NL Sonar, TP Valsala, Y Kulkarni, T Vincent, and A Kumar. 2014. "Removal of Ruthenium from High-Level Radioactive Liquid Waste Generated During Reprocessing of Spent Fuel," Desalination and Water Treatment 52(1-3):514-25. 10.1080/19443994.2013.848655.

Soelberg, NR, TG Garn, MR Greenhalgh, JD Law, R Jubin, DM Strachan, and PK Thallapally. 2013. "Radioactive Iodine and Krypton Control for Nuclear Fuel Reprocessing Facilities," Science and Technology of Nuclear Installations. 10.1155/2013/702496.

Swider-Lyons, KE, CT Love, and DR Rolison. 2005. "Selective Vapor Deposition of Hydrous $\mathrm{RuO}_{2}$ Thin Films," Journal of the Electrochemical Society 152(3):C158-C62. 10.1149/1.1859713.

Voskresenskaya, YA, OA Ustinov, and SA Yakunin. 2014a. "Ruthenium Capture from the Gas Phase during Reprocessing of Spent Uranium-Plutonium Nitride Fuel from Fast Reactors," Atomic Energy 115(3):187-190.

Voskresenskaya, YA, OA Ustinov, and AY Shadrin. 2014b. "Catching $\mathrm{RuO}_{4}$ on Solid Sorbents," Atomic Energy (New York, NY, US) 117(1):52-56. 10.1007/s10512-014-9887-z.

Vujisić, L, and R Nikolić. 1982. “Adsorption of Gaseous Ruthenium Tetroxide by Various Sorbents, II, pp. 123-130 in Proceedings of the 17th DOE Nuclear Air Cleaning Conference, Harvard Air Cleaning Laboratory, Cambridge, MA.

Weisenburger, S, and K Weiss. 1980. "Ruthenium Volatility Behavior During HLLW Vitrification in a Liquid-Fed Ceramic Waste Melter," Scientific Basis for Nuclear Waste Management 2:901-10. 10.1007/978-1-4684-3839-0_108. 